\title{
EFFECT OF WATER LEVEL FLUCTUATIONS ON FISHERY AND ANGLERS' CATCH DATA OF ECONOMICALLY UTILISED FISH SPECIES OF LAKE BALATON BETWEEN 1901-2011
}

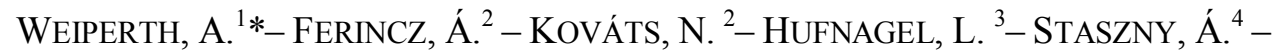 \\ KERESZTESSY, K. ${ }^{5}-$ SZABÓ, I. ${ }^{6}-$ TÁTRAI, I. $^{7} \dagger$-PAULOVITS, G. ${ }^{7}$ \\ ${ }^{1}$ Hungarian Academy of Sciences, Centre for Ecological Research, Danube Research Institute \\ H-2131 Göd, Jávorka S. u. 14. \\ (phone: +36-20-3916-468; fax:+36-2-346-023) \\ ${ }^{2}$ University of Pannonia, Department of Limnology \\ H-8200 Veszprém, Egyetem u. 10. \\ (phone/fax: +36-88-624747) \\ ${ }^{3}$ Szent István University, Faculty of Agricultural and Environmental Science Gödöllö, H-2100, \\ Páter Károly utca 1. (phone: +36-1-294-9875) \\ ${ }^{4}$ Szent István University, Department of Fish Culture \\ H-2100 Gödöllö, Páter K. út 1. \\ (phone/fax: +36-70-395-0905) \\ ${ }^{5}$ Vashal Bt. \\ H- 2234 Maglód, Darwin u. 7. \\ (phone: +36-30-546-2266) \\ ${ }^{6}$ Balaton Fish Management Non-Profit Ltd. \\ H-8600 Siófok, Horgony u. 1. \\ (phone/fax: +36-84-519-630) \\ ${ }^{7}$ Hungarian Academy of Sciences, Centre for Ecological Research, Balaton Limnological \\ Institute \\ 8237 Tihany, Klebelsberg Kunó u. 3 \\ (phone: +36-87-448-244) \\ *Corresponding author \\ e-mail: weiperth.andras@okologia.mta.hu \\ (Received $20^{\text {th }}$ Feb 2014 ; accepted $22^{\text {nd }}$ July 2014)
}

\begin{abstract}
Surveys aiming at analysing spatial and temporal changes of the fish stock of Lake Balaton have an almost 100 year history. Drastically low water levels which could be observed in the past years and which were most probably caused by global climate change provide a good reason to study population dynamic changes induced by water level fluctuations. The present study attempts to give a historical description of changes in the catch data of economically utilised fish species in relationship with water level fluctuations, based on catch data of the Balaton Fish Management Non-Profit Ltd. (predecessor: Lake Balaton Fishing Ltd.) and its predecessors, covering a 110-year period.
\end{abstract}

Keywords: Lake Balaton, fisheries and anglers catch data, water level fluctuations, non-indigenous species 


\section{Introduction}

Shallow lakes are more vulnerable to human activities and natural changes than deep ones. Shallowness can be measured through the dynamic ratio of a lake and lakes of similar shallowness can be compared in terms of sensitivity and vulnerability to various stresses. Several shallow lakes and communities in their basins experience disastrous changes due to lake and watershed mismanagement as well as climate change. Due to water management interventions, several natural lakes apply water conveyance from another watershed to improve water balance and manage level drop and/or large fluctuation. This problem exists in most shallow lakes from Europe and North-America (Jeppesen et al., 2005, Lyche-Solheim et al., 2013).

Several scientific studies have found that Lake Balaton does not show extreme characteristics as compared to other lakes in Central Europe, but the drainage area of Lake Balaton is very sensitive to both climate changes and human impacts (Padisák, 1998, Padisák et al., 2006, Dokuil et al., 2010). Its surroundings have been inhabited since the Stone Age; however, heavy human impact can be recognized during the past 6000 years (Korponai et al., 2009). Eutrophication was a common problem of Lake Balaton in 1960-1990, though the level of seriousness varies from very serious to acceptable (Specziár and Vörös, 2001, Istvánovics et al., 2007). The backwaters and Lake Balaton have water level problems due to water overuse or climate change. Dropping water level and shrinking of surface area always result in deterioration of water quality and loss of aquatic habitats (Scheffer et al., 2006). Water quality and level improvement measure applied include stopping or restricting agricultural activities, sewage treatment, dredging, biomanipulation, wetland restoration with filtration functions, direct runoff control, soil treatment to immobilize phosphorus and pesticides, etc. (Tátrai and Istvánovics, 1986, Mátyás et al., 2004, Sipkay et al., 2007, Korponai et al., 2009, Erős et al., 2012). Magnitude of measures (spending) is neither proportional to the seriousness of the problem nor to the population affected but it is more a function of the economic power of the countries (Várkuti et al., 2008). Most European shallow lakes and watersheds have a management plan developed but these plans do not entirely reflect the total economic value of the lakes and these tendencies are observed on Lake Balaton and the drainage area (Bíró et al., 2002, Sály et al., 2011).

The majority of ecological studies review the issues of short-term (maximum one season-long) observation but long-term research is becomes more important these days (Specziár and Bíró, 1998) because the exact trends of the physical and chemical processes within the water body and population dynamics of the species which live in them as well as changes in field use on drainage area are based on these studies (Smith, 2003, Erös et al., 2012). Assessing the results of the long-term fisheries catch data we draw not only the conclusion about the population of fish species and processes in community ecology but can important elements of the ecological condition of water bodies, too. Using this knowledge, we can determine the ecological and biological framework of conservation and restoration (Hobbs and Norton, 1996, Daskalov, 2002, Van De Bund et al., 2002, Mátyás et al., 2004, Søndergaard et al., 2008).

Based on long-term analysis we can receive a better picture of the changes in the quality of the environment and thereby the past and current trends and changes will be easier to interpret (Sipkay et al., 2009, Verasztó et al., 2010, Vadadi-Fülöp et al., 2012). 


\section{Literature of history of fisheries research on Lake Balaton}

There are detailed, historical data available on the size and composition of the fish fauna of Lake Balaton, including mosaic-like pattern, temporal and spatial changes (Vutskits, 1897, Lukács, 1932, Bíró, 1978, 1983, 1997, 2000, Paulovits et al., 1991, 1994, Ponyi 2001, Szabó and Héri, 1998, Specziár et al., 1998, Tölg et al., 1998, Tátrai et al., 2000. Harka and Sallai, 2004, Weiperth et al., 2008, 2009, Specziár, 2010, Takács et al., 2011, Ferincz et al., 2011, 2012, Specziár et al., 2013.). Drastically low water levels which appeared several times during the past years and which are considered as a consequence of global climate change (Lake et al., 2001, Somlyódy and Honti, 2005, Istvánovics et al., 2007) might have significantly influenced the dynamics of economically utilised fish stocks, including exotic species. These changes support the necessity of research started quite recently which seek relationships between water level and population dynamic changes of fish stocks (Bíró, 1978, 2000b, Paulovits et al., 2007, Korponai et al., 2010, Weiperth et al., 2008, 2009, Specziár, 2010).

The present study, following this line, attempts to give a historical overview of the changes in the catch of some economically important fish species in relation to water level fluctuations based on long-term fisheries and anglers' catch data, covering a 110year period. Also, some careful assessment is given on the relationship between catch data and magnitude of the water level fluctuations. In addition to catch data, data on stocking and outfishing on fisheries ponds and lakes are used to describe the temporal changes in the stock of eel and other, economically utilised non-native fish species. There have been attempts to stock non-native fish into Lake Balaton since the $19^{\text {th }}$ century, however, large-scale stocking was started in the 1960's, when species which were considered economically and biologically important (gibel carp, eel, Chinese carps: grass carp, silver carp, bighead carp) were released into Lake Balaton and the surrounding fish ponds in relatively high quantity (Pintér, 1980, 2002, Bíró 2000a,b, 2001, Paulovits et al., 2007, Weiperth et al., 2009, Specziár, 2010, Ferincz, 2011).

\section{Material and methods}

\section{Study area}

Lake Balaton is the largest shallow lake in Central Europe, and it is also a characteristic element of the hydrology of Hungary. Its watershed covers $5774 \mathrm{~km}^{2}$, the area of its water surface is exactly $594 \mathrm{~km}^{2}$. Length of the lake is $77 \mathrm{~km}$, the largest width is $12 \mathrm{~km}$, the smallest width is $1.5 \mathrm{~km}$ (Fig. 1.). In comparison to the size of the water basin, the water depth is rather shallow, with an average of 3-4 ms, the deepest being $11 \mathrm{~m}$ in the so-called Tihany-well.

Its bed was artificially modified in the 1800's, afterwards the Kis-Balaton was dried out. In the $19^{\text {th }}$ century a sluice was built at Siófok, on the South of the lake, which connected Lake Balaton to the River Danube. Through the sluice, the water level of the lake was controlled and lowered, which resulted in the partial drying up of the KisBalaton. The Kis-Balaton Wetland functioned as a natural filter zone, retaining nutrients carried by River Zala. Disappearance of the natural filter zone resulted in the increase of nutrient load in Lake Balaton which in turn was one of the main factors causing the serious eutrophication of the lake by the 1960's. The Kis-Balaton Water Protection System was built to protect the water quality of the lake via retaining nutrients (Pomogyi, 1993, Korponai et al., 2009). 
The natural outflow of the lake is provided by the Sió-Canal. Water transport of the Canal, as well as its water-tapping and the water level are controlled by the sluices at Siófok, the barrage at Balatonkiliti, as well as the works in the mouth of Sió-Canal. The maxiumum capacity of the sluices are $80 \mathrm{~m}^{3} / \mathrm{s}$ (in practice $50 \mathrm{~m}^{3} / \mathrm{s}$ ) (Zákonyi 2004).

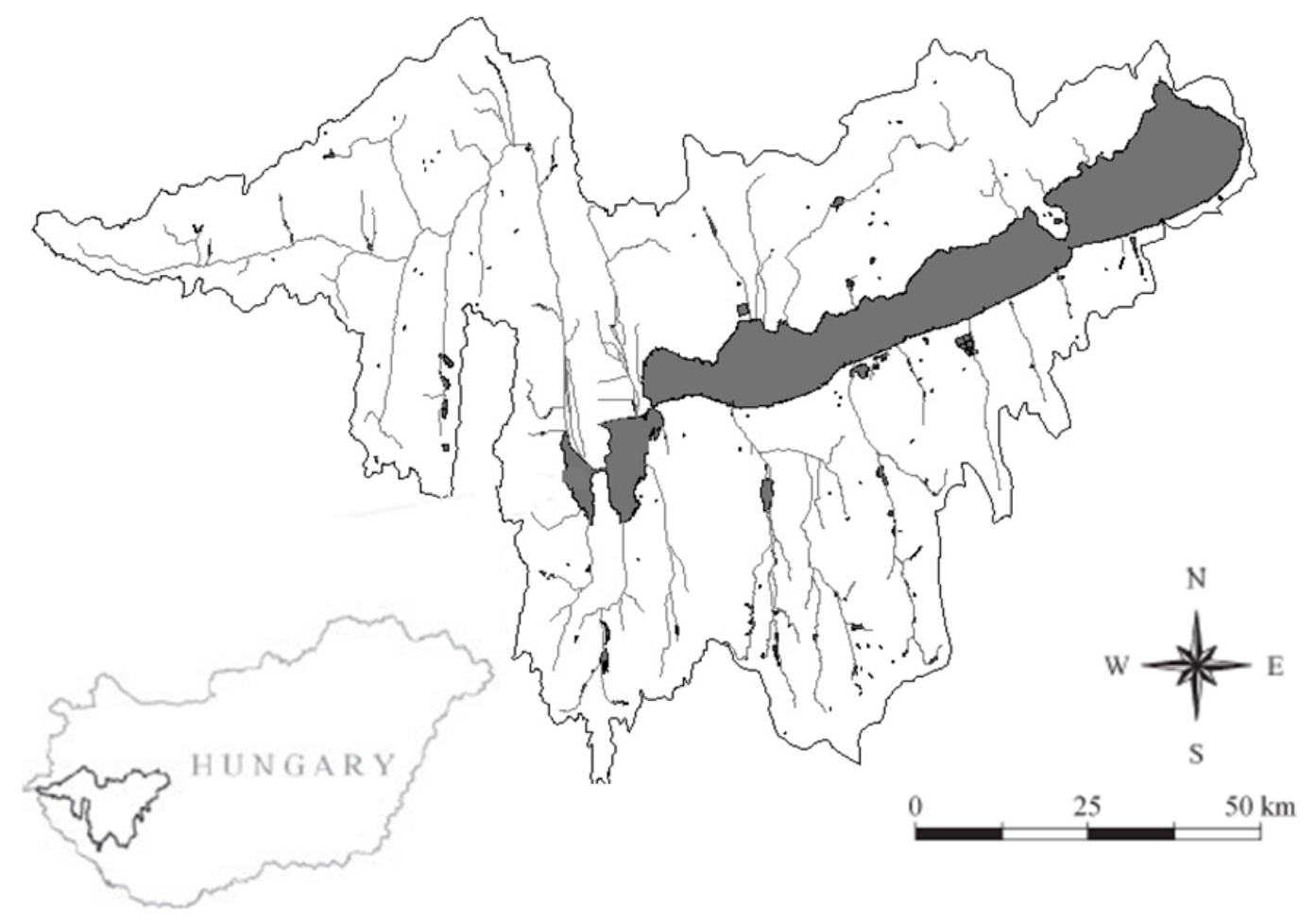

Figure 1. Overlooking map of the Balaton catchment

The water balance of the lake is characterised by an average of in the last 110 years: $621 \mathrm{~mm}$ precipitation, $908 \mathrm{~mm}$ inflow, $800 \mathrm{~mm}$ evaporation, $610 \mathrm{~mm}$ water-tapping on the Sió-Canal. Water usage (drinking water, industrial, agricultural) is the smallest in absolute value among all the elements. It describes the difference between the quantities of water that were removed from the lake for any type of use and those that were pumped back after use. The average change of water-level within a year was $30 \mathrm{~cm}$ but in 1921 the annual water-level fluctuation was $104 \mathrm{~cm}$ (Fig. 2.).

Until the mid 1980s (for more than 60 years) inflow accounted for $60 \%$, precipitation for $40 \%$ of the input in the water budget. In the years after this period the ratio began to change - primarily due to the significant decrease in the inflow to the lake. The proportion of the inflow gradually receded and the proportion of precipitation increased. In the first half of the 2000's the proportion of inflow dropped under 50\% and precipitation accounted for more than $50 \%$ of all the input - this was the reversal of the previous period. After this, as more years with more precipitating followed, the proportions of inflow and precipitation moved back towards the values which traditionally characterized an average water budget. This phenomenon directs our attention to the following: prolonged and unidirectional meteorological - and the resulting hydrological - extremes can temporarily cause drastic 
changes in the historically accepted proportions between the elements of the input side of the water budget (EuLakes, 2012a,b).

\section{Used data bases and statistical analyses}

Our surveys were based on the long-term catch data of the Balaton Fish Management Non-Profit Ltd. (predecessor: Lake Balaton Fishing Ltd.) and of the National Federation of Hungarian Anglers (MOHOSZ). In order to gain more detailed information, data provided by the War Historical Archives of Department of Defence and National Agricultural Library and Documentation Centre were also processed. 100-year water level data were obtained from the database of the General Director of Water Management (www.hydroinfo.hu).

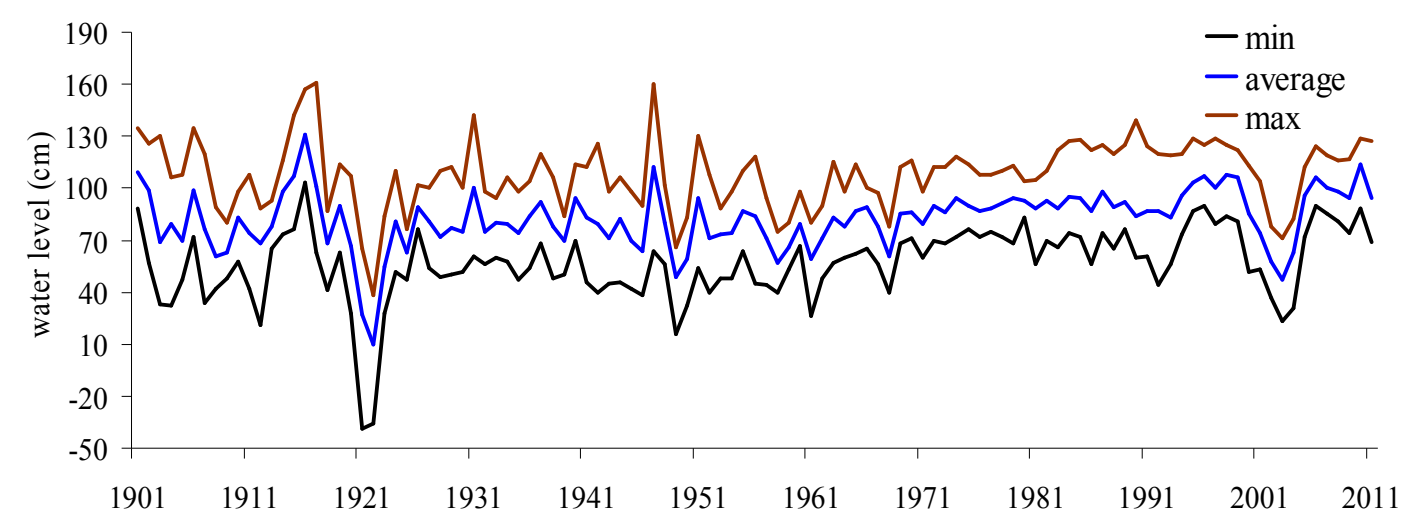

Figure 2. Changes in water level between 1901 and 2011

Databases were analysed using PAST software (Hammer et al., 2001). Of statistical methods, in order to establish relationship between water levels and catch data of fish species reproducing in Lake Balaton cross-correlation was applied, population growth of non-indigenous species was analysed by polynomial regression, finally water levels and general catch data were compared using Pearson's correlation (Olden and Neff, 2001, Reizigel et al., 2007, Bíró, 2011, Probst et al., 2011). In case of species where correlation was found between catch data and water level changes, correlation coefficients and correspondence values are indicated in the axes of the figures. In order to avoid possible data loss, correlation coefficients have not been normalised.

\section{Investigated fish species}

Our surveys covered those 11 species which are presently economically important: eel (Anguilla anguilla Linnaeus, 1758), asp (Aspius aspius Linnaeus, 1758), catfish (Silurus gleanis Linnaeus, 1758), pike (Esox lucius Linnaeus, 1758), pikeperch (Sander lucioperca Linnaeus, 1758), Volga pikeperch (Sander volgensis Glemin, 1788), carp (Cyprinus carpio Linnaeus, 1758), sabre carp (Pelecus cultratus Linnaeus, 1758), including the non-indigenous grass carp (Ctenopharyngodon idella Valenciennes, 1844), bighead carp species (Hypopthalmichthys molitrix Valenciennes, 1844, $H$. nobilis Richardson, 1845) and their hybrids, as well as Gibel carp (Carassius gibelio Bloch, 1782). Relatively low number of species involved might be explained by the fact that although there are altogether 32 species occurring in the lake (Takács et al., 2011), 
of which 20-24 can be regarded as common, only 15-17 species can be found in the catch (Pintér, 1980, 2002, Weiperth et al., 2008, 2009, Specziár, 2010). Analysing catch data of introduced alien species (Chinese carps: grass carp, bighead, silver carp and their hybrids), which are utilised economically but do not reproduce in the lake, temporal changes in their stock size can be discussed. The recruitment in these species does not happen in a natural way but only via stocking, in contradiction to gibel carp, which has appeared in the statistics with fluctuating catch data since it was first recorded in 1959 in the southern fish ponds and in Kis-Balaton. Catch data of Lake Balaton include species utilised only for a shorter period. Data of these species were not analysed statistically (Table 1.).

Table 1. Exploited fish species of Lake Balaton

\begin{tabular}{|c|c|c|c|c|}
\hline Fish species & $\begin{array}{l}\text { Origin of } \\
\text { Balaton } \\
\text { catchment }\end{array}$ & $\begin{array}{l}\text { Reproductive } \\
\text { strategy }\end{array}$ & $\begin{array}{c}\text { Year range of } \\
\text { data for fishery's } \\
\text { period }\end{array}$ & $\begin{array}{c}\text { Year and mass in } \\
\text { ton of maximum } \\
\text { catch }\end{array}$ \\
\hline Anguilla anguilla & native & $\begin{array}{c}\text { does not } \\
\text { reproduce } \\
\text { (catadromous) }\end{array}$ & 1961-today & 1996: $509 \mathrm{t}$ \\
\hline $\begin{array}{c}\text { Ctenopharyngodon } \\
\text { idella }\end{array}$ & $\begin{array}{l}\text { non-native } \\
\text { (Far East) }\end{array}$ & $\begin{array}{l}\text { escaped from } \\
\text { fish farm }\end{array}$ & 1975-today & 1994: $10.7 \mathrm{t}$ \\
\hline Aspius aspius & native & lithophil & 1901-today & 1929: $29.9 \mathrm{t}$ \\
\hline Alburnus alburnus & native & phyto-lithophil & $\begin{array}{c}1952-1960,1967, \\
1975\end{array}$ & 1952: $49.9 \mathrm{t}$ \\
\hline Pelecus cultratus & native & pelagophil & $1901-2011$ & 1965: 354.4 \\
\hline Tinca tinca & native & phytophil & 1950-1989 & 1967: $1.06 \mathrm{t}$ \\
\hline Carassius gibelio & $\begin{array}{l}\text { non-native } \\
\text { (Far East) }\end{array}$ & phytophil & 1959-today & 1996: 29.9 t \\
\hline Cyprinus carpio & native & phytophil & 1901-today & 1929: $83 \mathrm{t}$ \\
\hline \multicolumn{5}{|l|}{ Hypopthalmichthys } \\
\hline $\begin{array}{c}\text { molitrix, } H . \text { nobilis, } \\
\text { H. molitrix } x H . \\
\text { nobilis hybrid }\end{array}$ & $\begin{array}{l}\text { non-native } \\
\text { (Far East) }\end{array}$ & $\begin{array}{l}\text { escaped from } \\
\text { fish farm }\end{array}$ & 1972-today & 2004: $437.9 \mathrm{t}$ \\
\hline Silurus glanis & native & $\begin{array}{l}\text { phytophil } \\
\text { (substratum } \\
\text { choosers) }\end{array}$ & 1901-today & 1953: $27.8 \mathrm{t}$ \\
\hline Esox lucius & native & phytophil & 1901-today & 1949: $40.8 \mathrm{t}$ \\
\hline $\begin{array}{c}\text { Onchorhynhus } \\
\text { mykiss }\end{array}$ & $\begin{array}{l}\text { non-native } \\
\text { (North } \\
\text { America) }\end{array}$ & $\begin{array}{l}\text { introduced for } \\
\text { aquaculture } \\
\text { utilization }\end{array}$ & $\begin{array}{c}\text { 1963-1991 } \\
\text { (drainage area) }\end{array}$ & 1986: $0.7 \mathrm{t}$ \\
\hline Perca fluviatlis & native & phyto-lithophil & $1924-55$ & 1947: $0.3 \mathrm{t}$ \\
\hline Lota lota & native & lito-pelagophil & $\begin{array}{l}\text { 1950-1959, 1996- } \\
1998 \text { (Zala River) }\end{array}$ & $\begin{array}{c}\text { 1950: } 0.075,1996: \\
0.063\end{array}$ \\
\hline Sander lucioperca & native & $\begin{array}{c}\text { phytophil (nest } \\
\text { sawners) }\end{array}$ & 1901-today & 1943: $236 \mathrm{t}$ \\
\hline Sander volgensis & native & $\begin{array}{l}\text { phytophil (nest } \\
\text { sawners) }\end{array}$ & 1950-today & 1953: $11 \mathrm{t}$ \\
\hline
\end{tabular}




\section{Results}

\section{Native fish species}

The origin of the eel still raises some questions, but it has become accepted that a native fauna element in Lake Balaton, although there are no reliable data on its early population size (Specziár, 2010). There were plans completed to stock eel for economic purposes by the 1950s', however the results of the so called 'eel project' which was started in 1961 are somewhat contradictory. The quantity of stocked juvenile eels already decreased in the middle 1970s' (Table 2.) (Gönczy and Tölg, 1997), but it showed an increase in trend till the fish kill in 1991, having its maximum quantity (509 t) in 1996, after the second big fish kill of 1995, then a continuous decrease started (Fig. 3.). The two most important methods for fishing were the electric trail-net, and eel traps placed at the Sió-sluice. Electric fishing was terminated in 1996, afterwards disparities between anglers' and fisheries catches disappeared. When correlating aggregated catch data and water-tapping quantity via the Sió-sluice, significant positive correlation was found $\left(\mathrm{R}^{2}=0.791 ; \mathrm{P}=0.018\right)$. Analysing relationship between anglers' catch data and annual average water levels, $\mathrm{R}^{2}=0.718(\mathrm{P}=0.0036)$ value was obtained.

Table 2. Introduction and catch of eel in five years cumulation value between 1961-2011

\begin{tabular}{|c|c|c|}
\hline Years & locating stock (million individuals) & total catch (t) \\
\hline $1961-1965$ & 10 & 3.6 \\
\hline $1966-1970$ & 15.7 & 78.7 \\
\hline $1971-1975$ & 15.8 & 121.4 \\
\hline $1976-1980$ & 15.0 & 184.8 \\
\hline $1981-1985$ & 14.6 & 581.9 \\
\hline $1986-1990$ & 8.0 & 642.9 \\
\hline $1991-1995$ & 4.0 & 1519 \\
\hline $1996-2000$ & - & 925 \\
\hline $2001-2005$ & - & 59.7 \\
\hline $2006-2011$ & - & 106.5 \\
\hline
\end{tabular}

In the most intensive fishing period of asp the highest average catch was $24 \mathrm{t}$ /year, which was achieved twice $(1928,1954)$. Afterwards, the catch was showed a decreasing trend till the 1990s'. From the 2000s', total catch has been showing again a decreasing tendency, with 0.3-5.6 t/year, nowadays being under 0.4 t (Fig. 4.). Negative correlation was found between catch data of asp and water level changes for years 4 and 8 (Fig 5.A.).

In case of catfish also a negative correlation was found for the periods between years 2-5, and 12-16 (Fig. 5.B.). Temporal pattern of the catch showed relatively low amplitudes. Total catch has never exceeded $28 \mathrm{t}$, but nowadays it hardly reaches $3 \mathrm{t}$. In addition, significant fish kills contributed to mortality (Fig. 4.).

Negative correlation is given between catch data of pike and water level changes for years 1-6 and 13-21 (Fig. 5.C.). Catch of pike in Lake Balaton is characterised by 
extreme years. From 1901-50, the average catch was 18 t/year, than after the 1960's a slow decrease could be observed. However, in certain years very high catches were recorded (Fig. 4.).

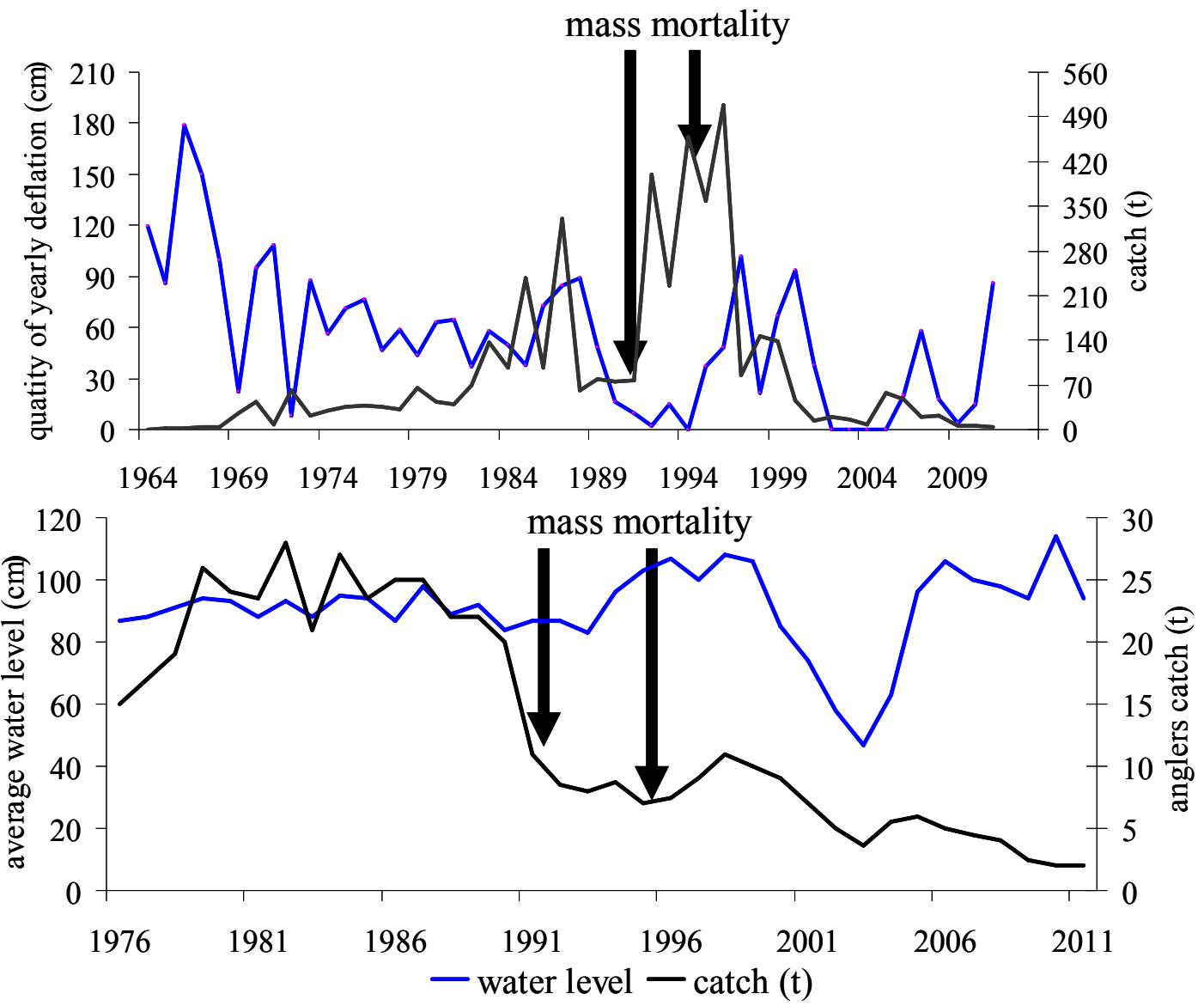

Figure 3. Eel fisherman and anglers catches in Lake Balaton between 1964-2011 (yearly totals $(t))$

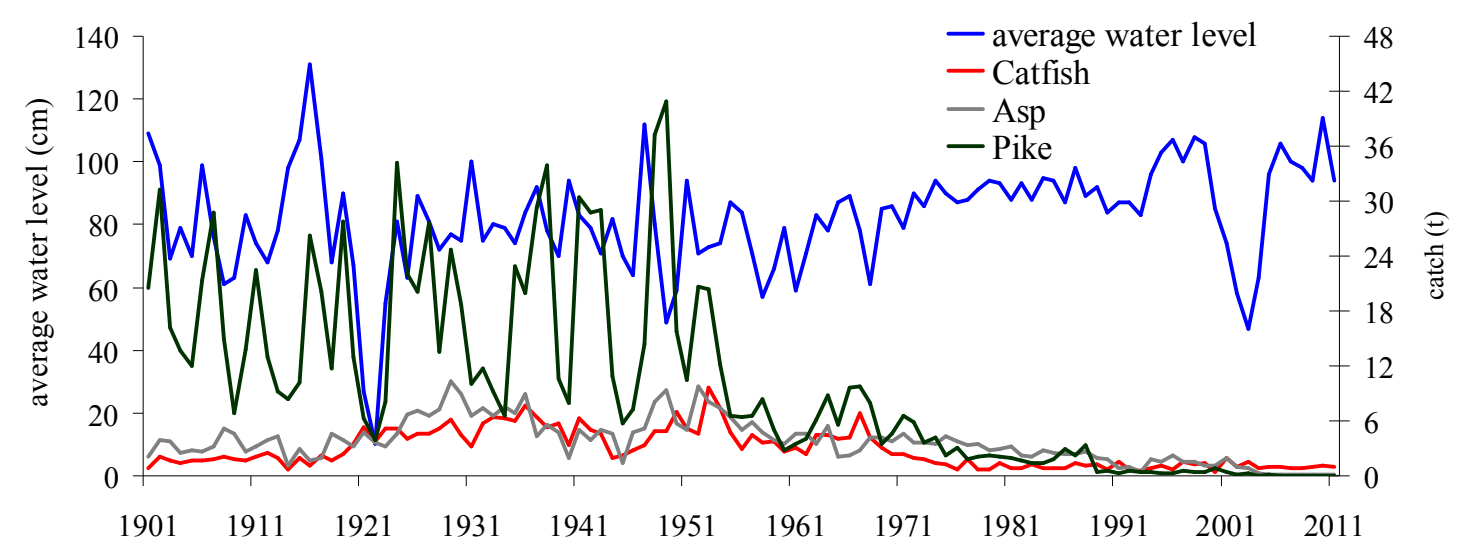

Figure 4. Catch of asp, catfish, pike in Lake Balaton between 1901-2011 (yearly totals (t)) 

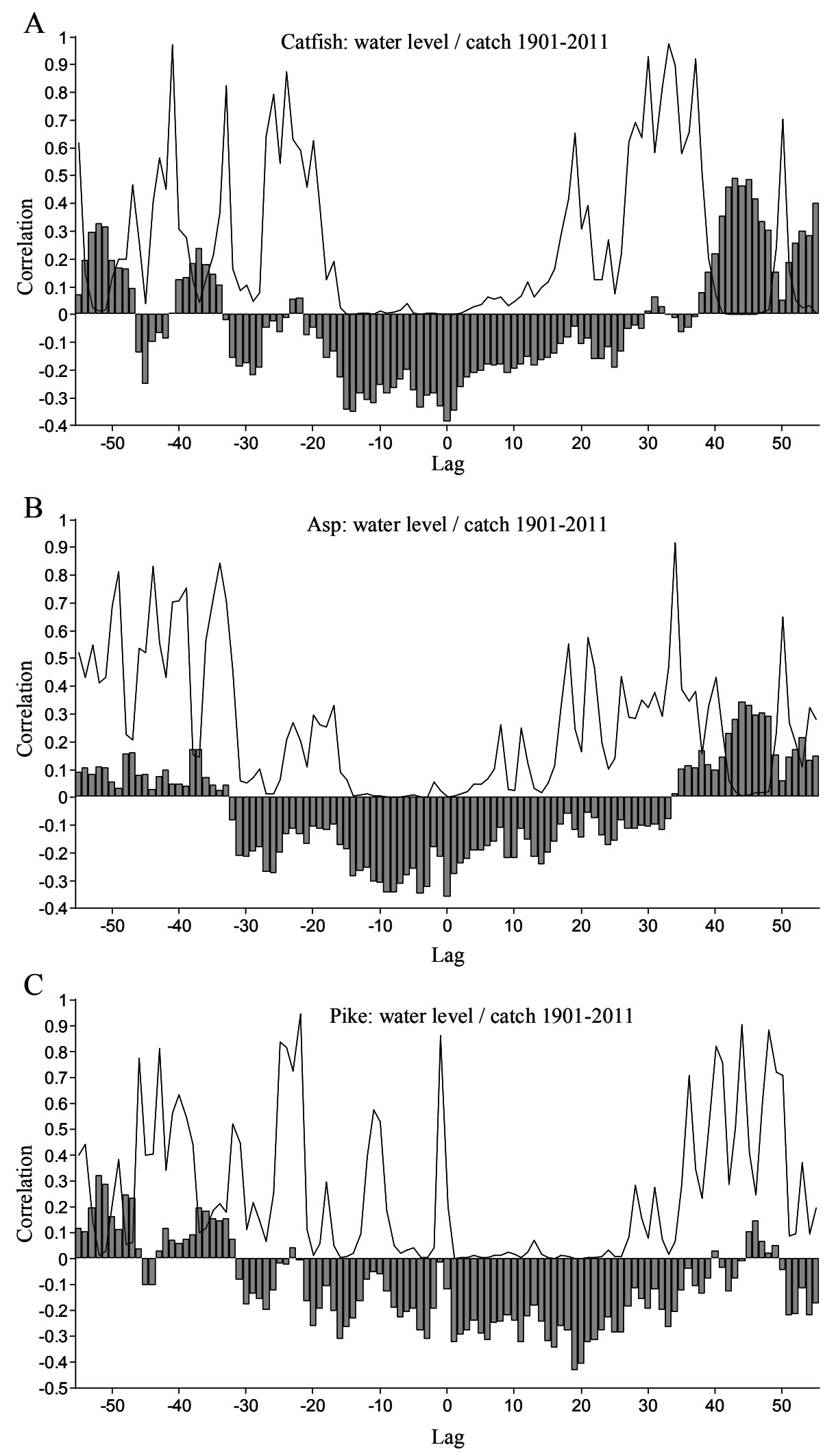

Figure 5. Cross-correlation between average annual water level and annual catches by commercial fisherman and anglers of catfish, asp and pike in Lake Balaton between 1901-2011 The lines mark the confidence limit. Lag number correspond to years. 
Pikeperch showed a maximum catch between 1930-1965 (average $150 \mathrm{t}$ ). In the past 10 years, the average has moved between 15.3-1.6 tons annually (Fig. 6.). Negative correlation was given for years 2-4, and 10-14 (Fig. 8.A.).

Volga pikeperch holds a special position, as already the first references mention its occurrence in Lake Balaton (Herman, 1887, Pintér, 2002), but catch data has included this species only from 1950. Catch data showed negative correlation from the second year (Fig. 8.B). Catch of the species has drastically decreased from the 1990s', nowadays only anglers' catch data include it, in an almost negligible ratio (0.4\%) (Fig. 7.).

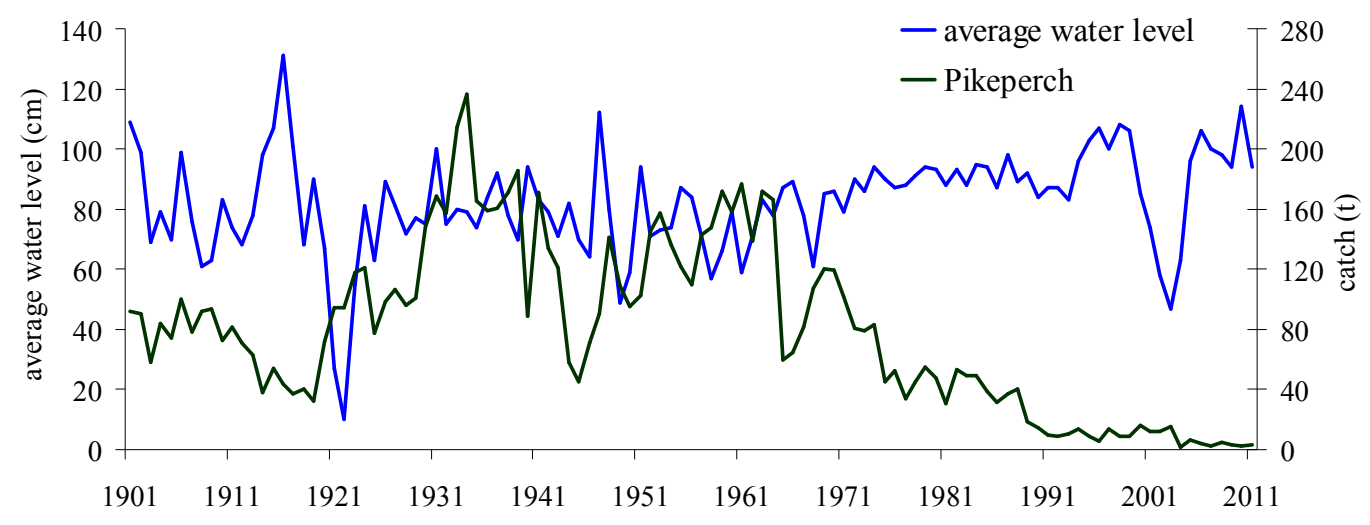

Figure 6. Catch of pikeperch in Lake Balaton between 1901-2011 (yearly totals ( $t$ ))

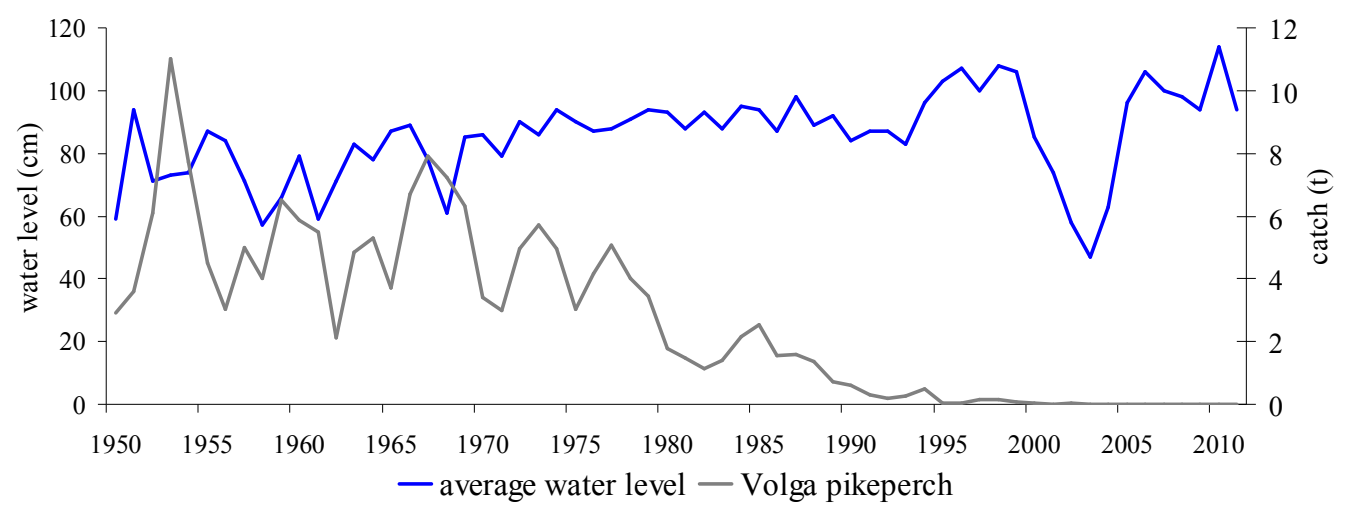

Figure 7. Catch of Volga pikeperch in Lake Balaton between 1950-2011 (yearly totals (t))

Carp has been intensely utilised from the beginning of large-scale fishery in Lake Balaton, due to its economic value. Also, this species is under heavy pressure by anglers as well. Its catch data showed high extremities between 1917-1975, than started to show a decreasing tendency, despite intense stocking (Fig. 9). Negative correlation is given between catch data of carp and water levels for years 6-18 (Fig. 11.A.).

When analysing catch data of sabre carp, it might be seen that from the late 1970s' the quantity of the catch has significantly decreased (Fig. 10). Negative correlation is given for the first 5 years and for years 10-15 (Fig. 11.B.) 

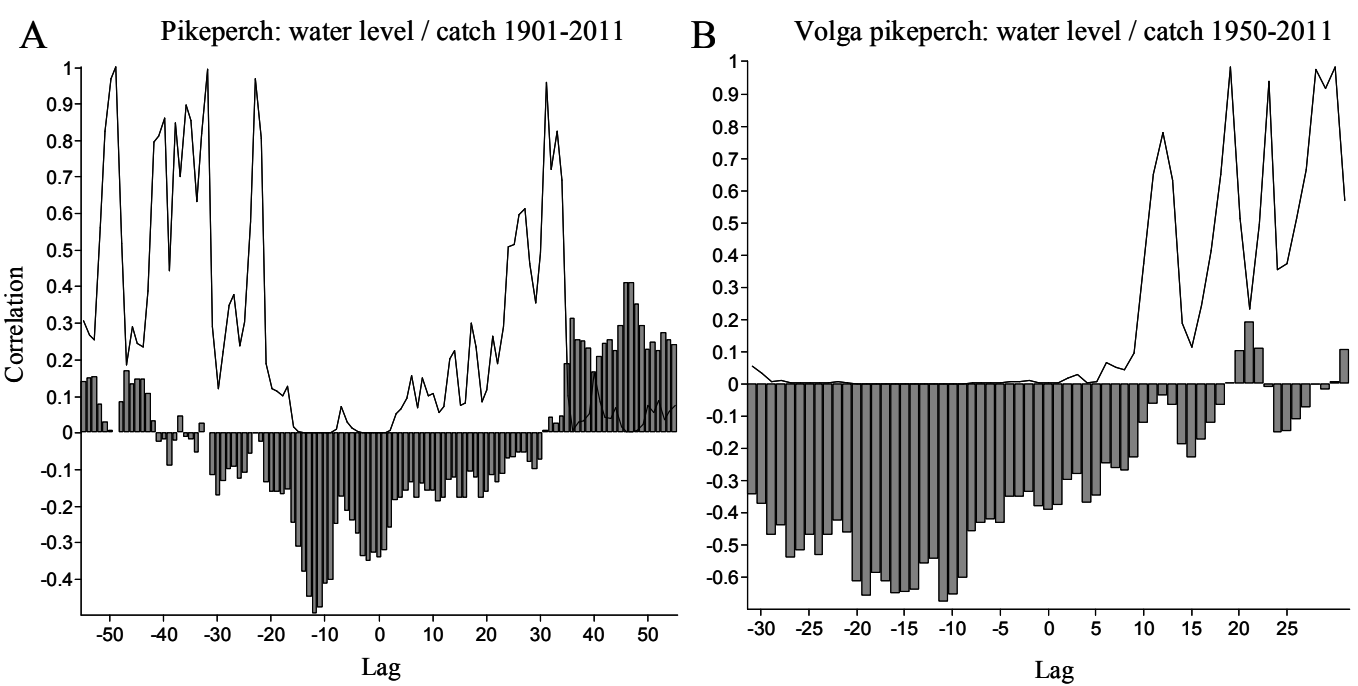

Figure 8. Cross-correlation between average annual water level and annual catches by commercial fisherman and anglers of pikeperch and Volga pikeperch in Lake Balaton between 1901-2011. The lines mark the confidence limit. Lag number correspond to years.

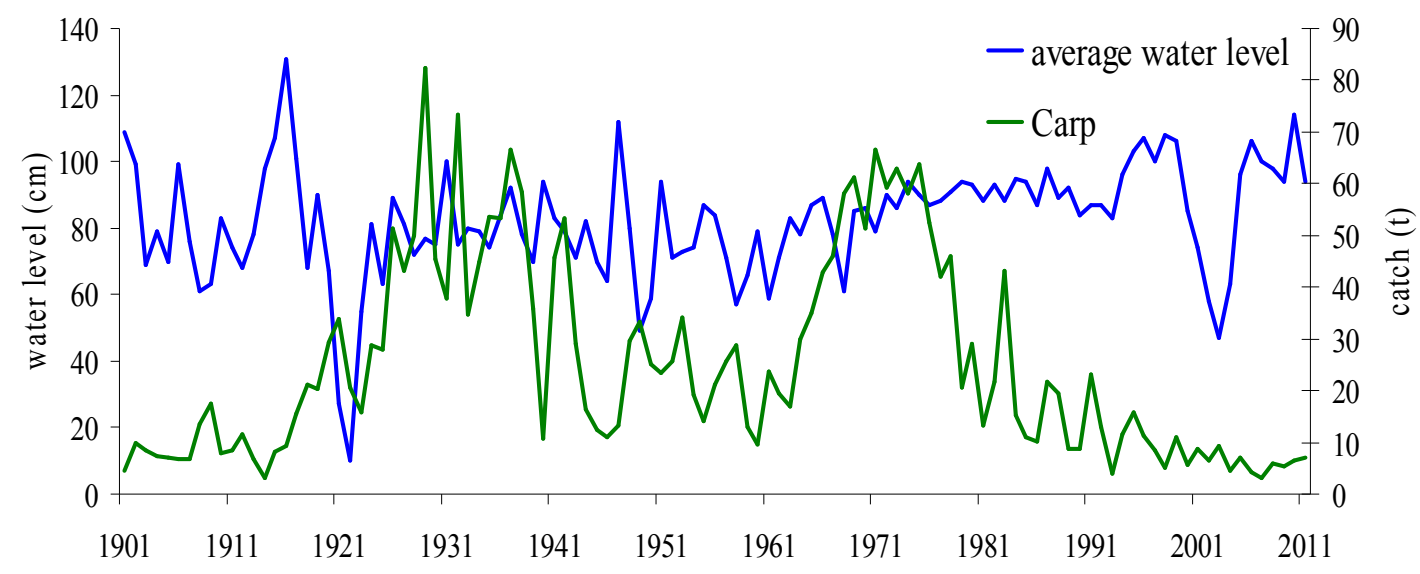

Figure 9. Catch of carp in Lake Balaton between 1950-2011 (yearly totals (t))

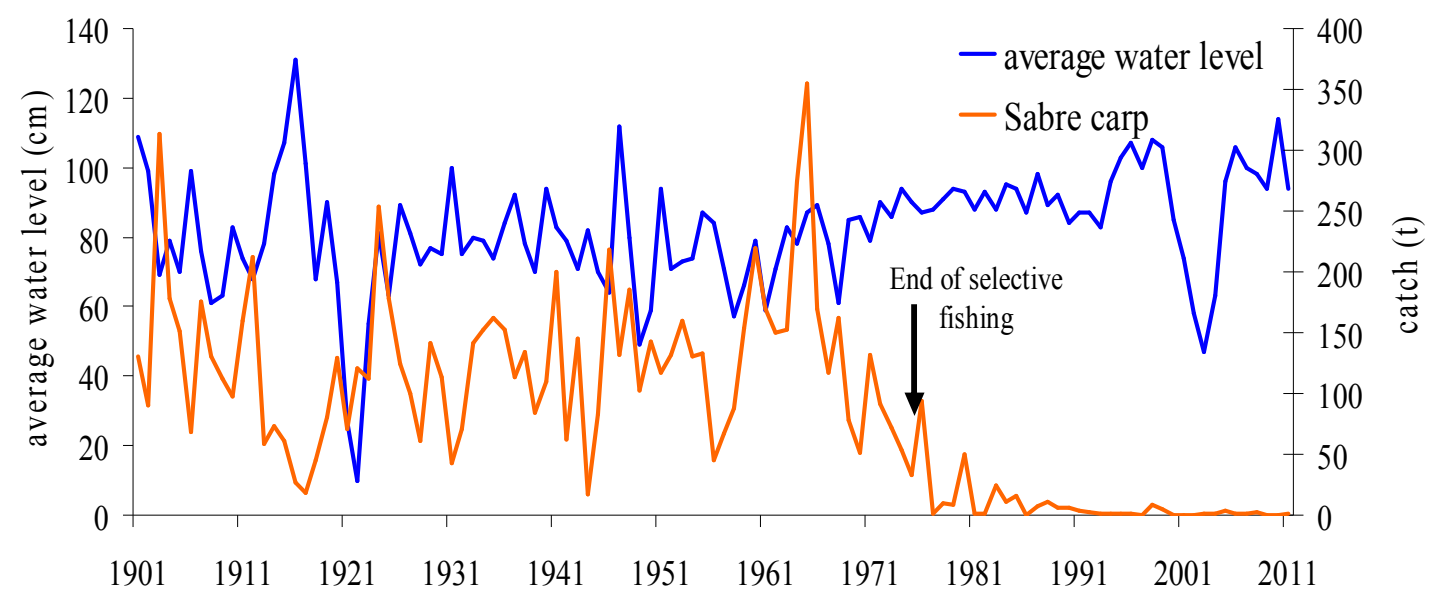

Figure 10. Catch of sabre carp in Lake Balaton between 1950-2011 (yearly totals (t)) 

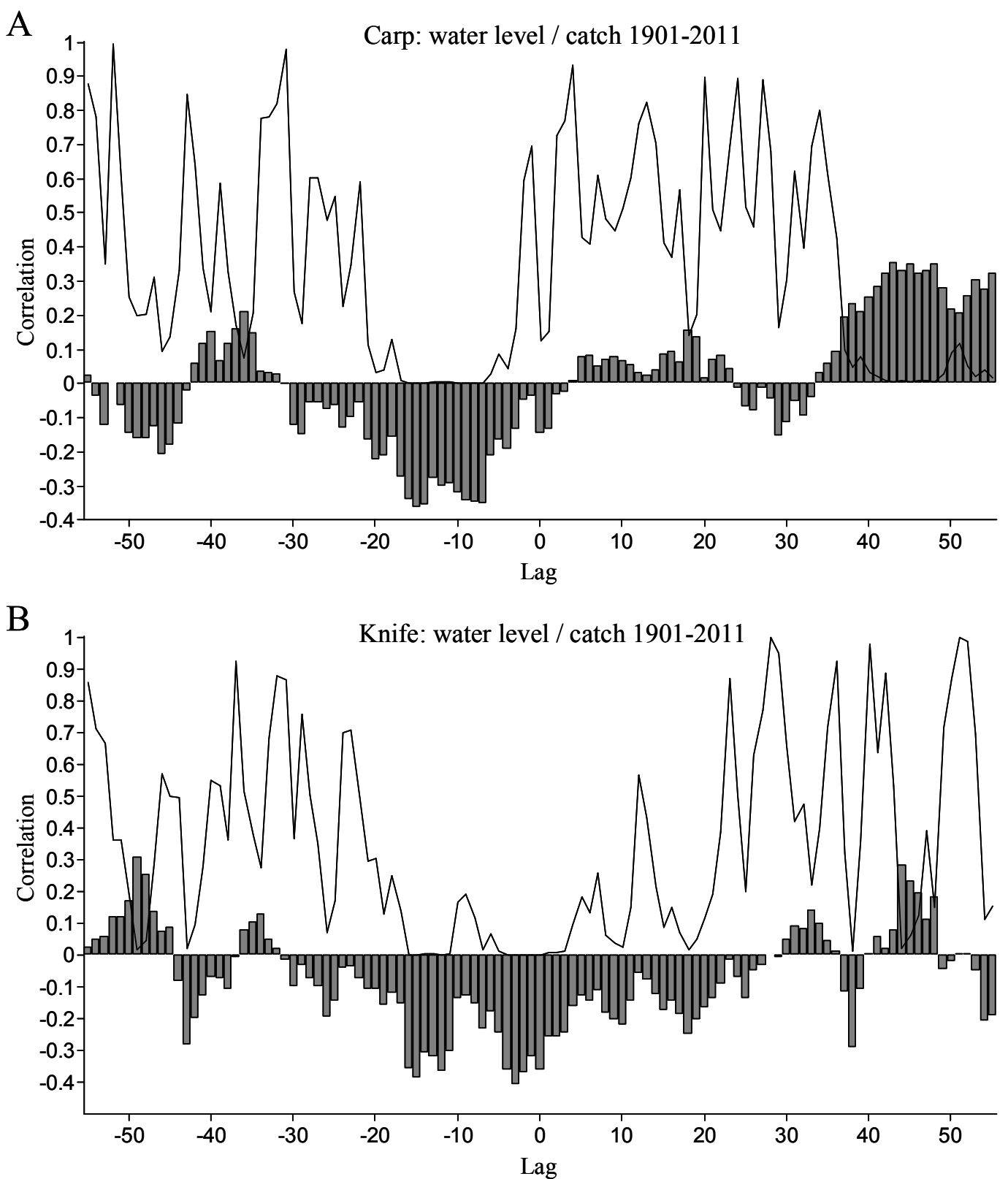

Figure 11. Cross-correlation between the average annual water level and annual catches of carp and sabre carp by commercial fisherman and anglers in Lake Balaton between 1901-2011. The lines mark the confidence limit. Lag number correspond to years.

\section{Non-native fish species}

Grass carp holds a specific status, as it has never been intentionally introduced to Lake Balaton. Still, catch of fisheries and anglers amounts to an annual 5 tons. Based on polynomial regression, catch data show an increasing trend $\left(\mathrm{R}_{\text {fisheries }}^{2}=0.671, \mathrm{p}_{\text {fisheries }}<\right.$ $\left.0.05 ; \mathrm{R}_{\text {anglers }}^{2}=0.551, \mathrm{p}_{\text {anglers }}<0.05\right)$ (Fig. 12., 13.). Correlation between catch of grass carp and average water levels gave a 0,674 value, $(\mathrm{p}=0.0012)$, meaning that there is a positive correlation: when the water level is higher, the catch of grass carp is also higher (Fig. 14.). 


$$
-233-
$$

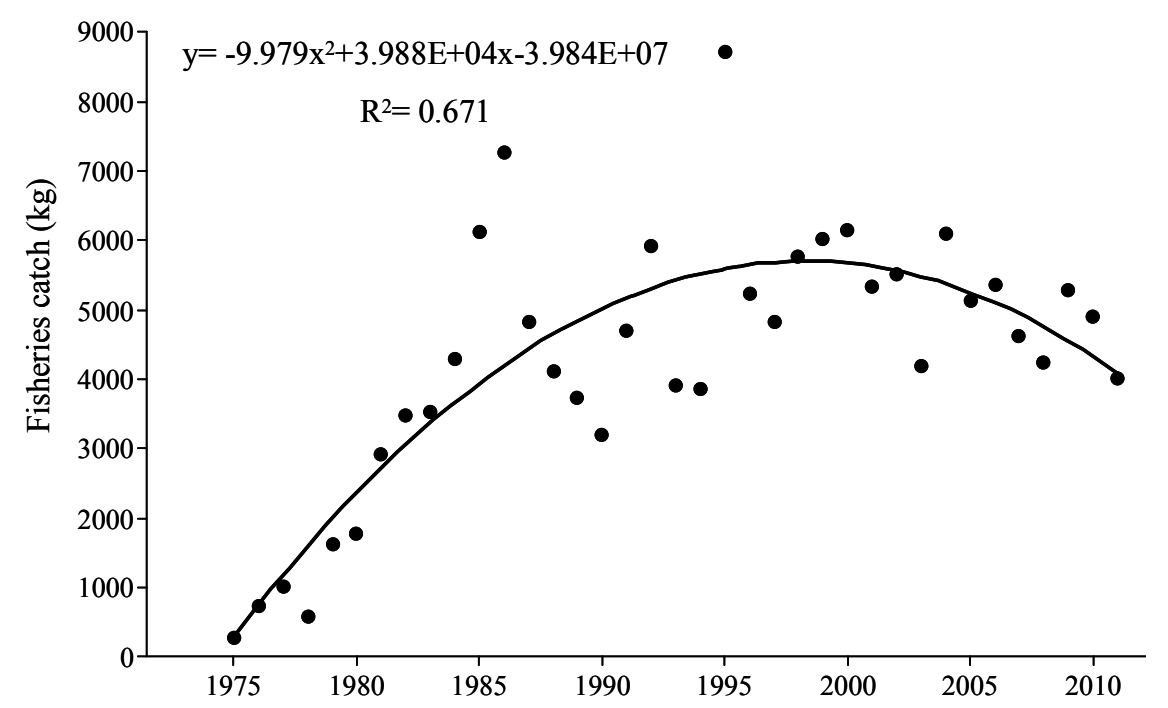

Figure 12. Fisheries catch of Grass carp in Lake Balaton between 1975-2011

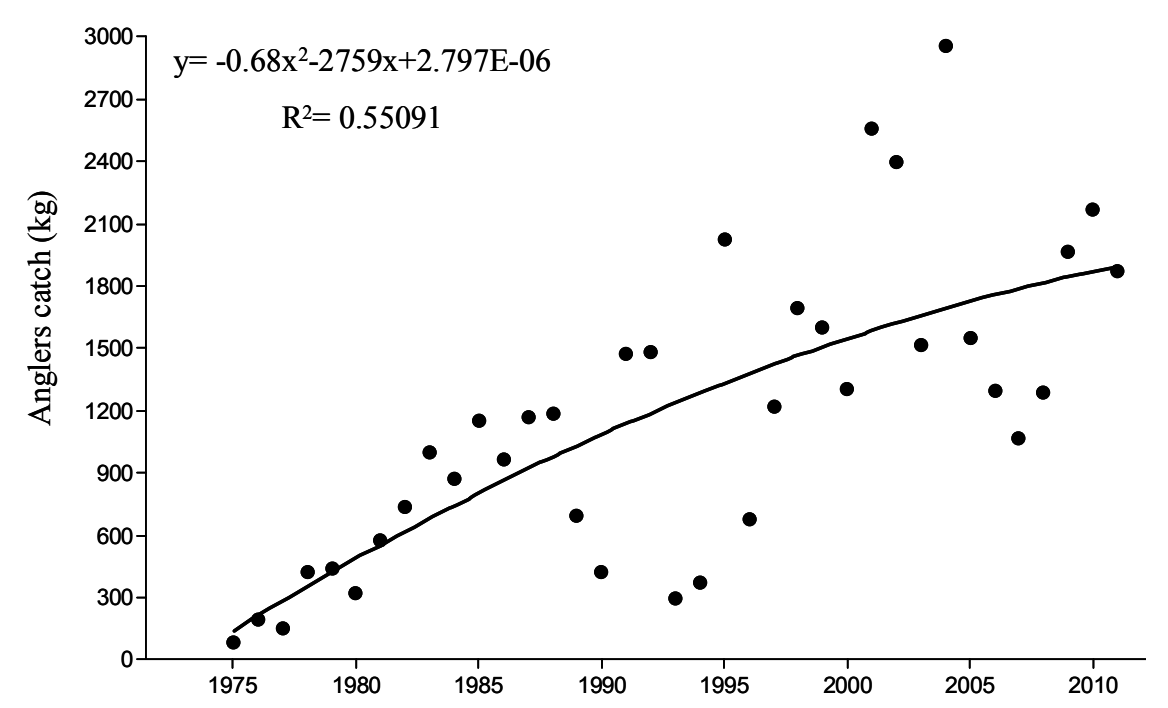

Figure 13. Anglers catch of Grass carp in Lake Balaton between 1975-2011

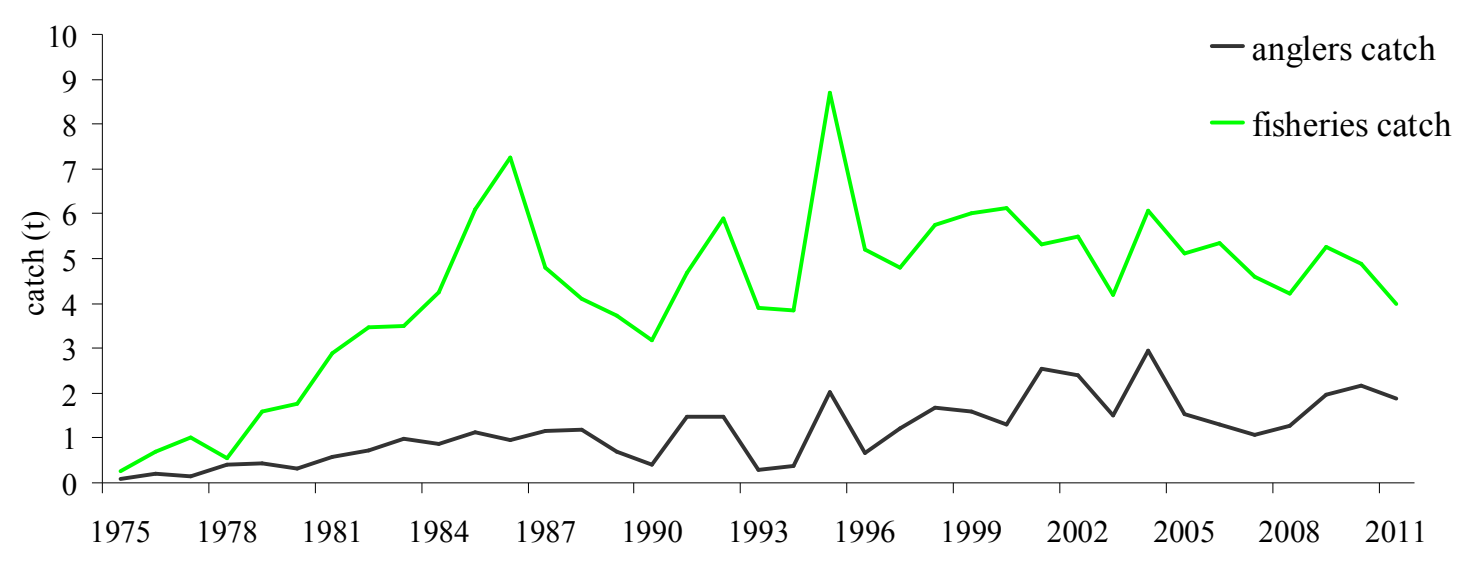

Figure 14. Grass carp catch in Lake Balaton between 1976-2011

APPLIED ECOLOGY AND ENVIRONMENTAL RESEARCH 12(1): 221-249. http://www.ecology.uni-corvinus.hu • ISSN 15891623 (Print) • ISSN 17850037 (Online) (c) 2014, ALÖKI Kft., Budapest, Hungary 
Bighead carp species were stocked to Lake Balaton between 1972 and 1983 (except in 1974-75). Altogether 1764580 two-year old specimens were released (with a biomass of $350098 \mathrm{~kg}$ ). After 1984 stocking was stopped (Specziár, 2010). The fishing of silver carp has become intensive in the lake by the 1990s' and still shows an increasing tendency $\left(\mathrm{R}_{\text {fisheries }}^{2}=0.833, \mathrm{p}_{\text {fisheries }}<0.05\right.$ (Fig. 15.) due to the application of new fishing techniques and selective fishing. Both species, as well as their hybrids have become one of the most important species of fisheries. The maximum catch was recorded in 2004 (437 tons). Since 2005, the average catch has been 293 tons (Fig. 16.).

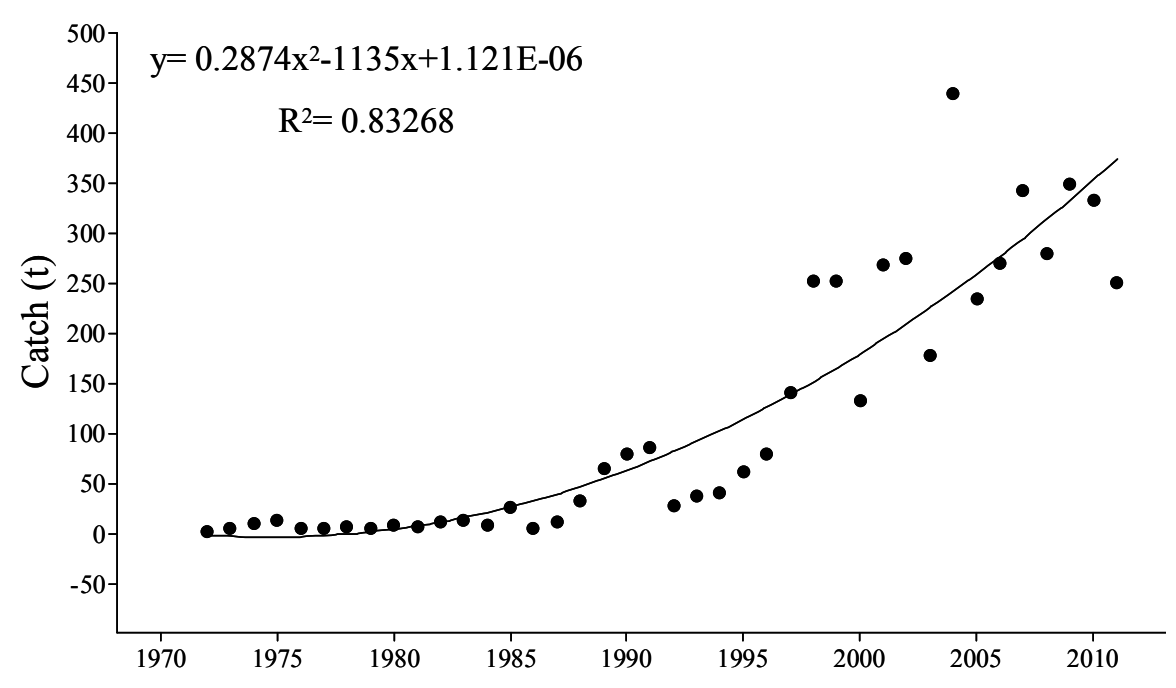

Figure 15. Polynomial regression of the catch of silver carp, bighead carp and their hybrids in Lake Balaton between 1972-2011

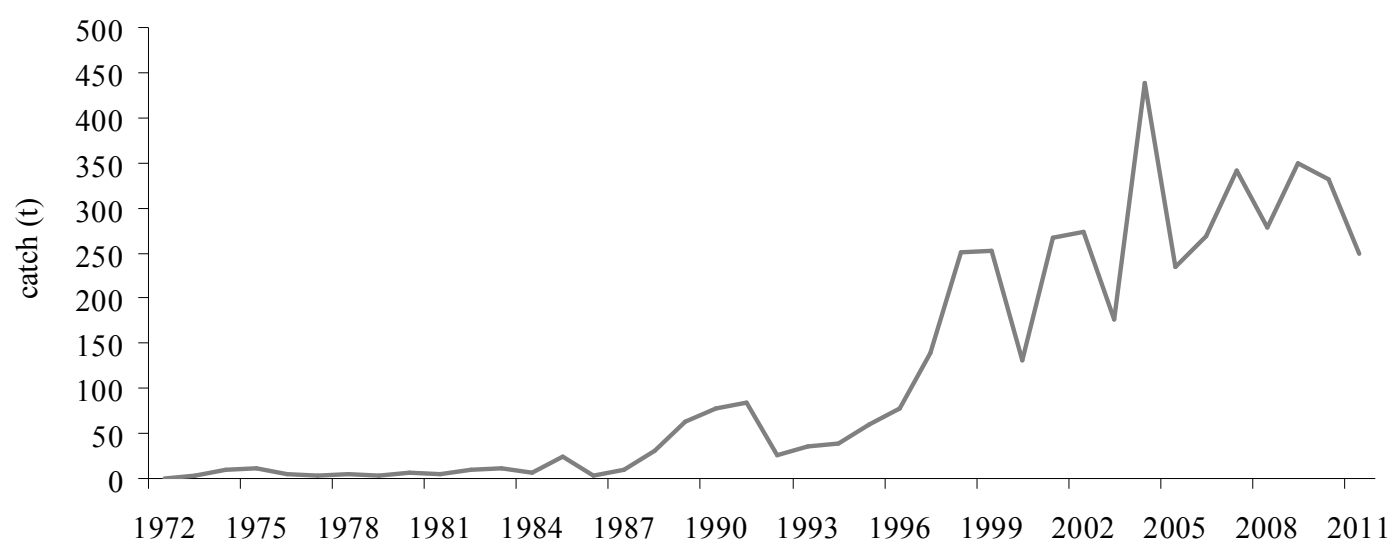

Figure 16. Catch of silver carp, bighead carp and their hybrids in Balaton between 1972-2011

In the catch data of the gibel carp, two outstanding figures appear: 7.7 tons in 1959 and 9.6 tons in 1960. There was a rapid increase in the second half of the 1980s' (1992: $23 \mathrm{t}$ ), than a fall to 4.4 tons in 1993. There was an app. $30 \mathrm{t}$ catch maximum in 1996, followed by a decrease. Between 1997 - 2011 the average annual catch was 4.6 tons (Fig. 17.). 


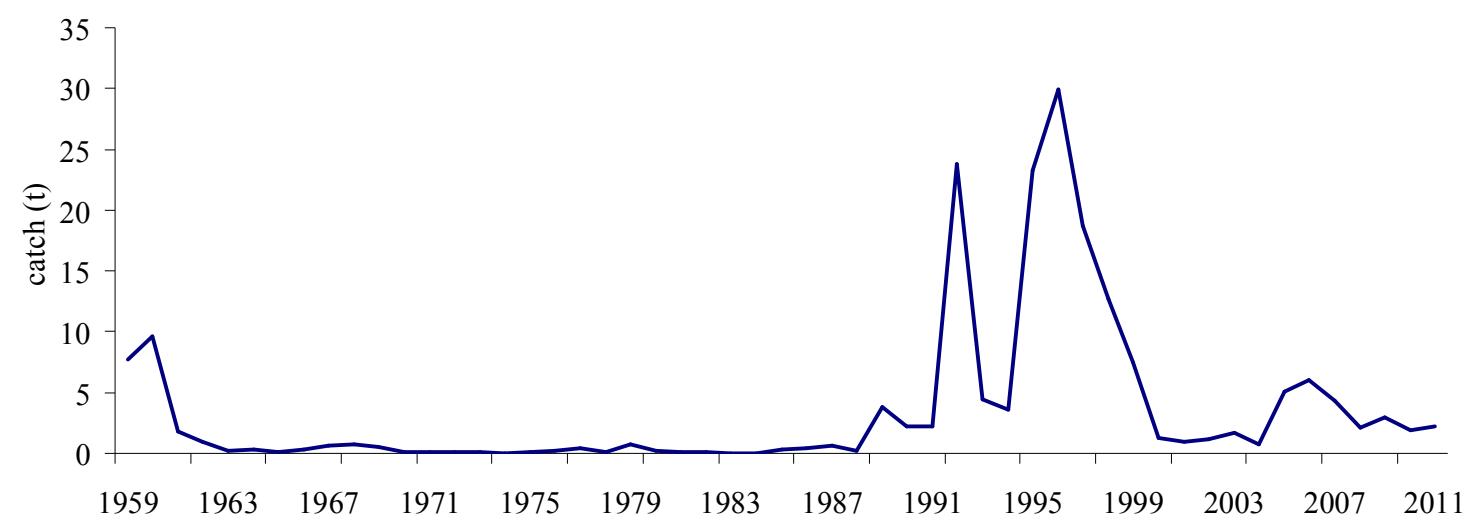

Figure 17. Catch of gibel carp in Lake Balaton catchment between 1959-2011

\section{Discussion}

\section{Changes in fisheries catch in Lake Balaton between 1901-2011}

The summarised fisheries catch data showed, that in the last 20 years the eel and the other non-native fish species (mainly the three Chinese carp species) gave 93\% of total fish catches in Lake Balaton (Fig. 18.). The 'A' fish category includes the fish species of high economical value: asp, carp, catfish, Chinese carp species, eel, pike, pikeperch and Volga pikeperch. The ' $\mathrm{B}$ ' fish category includes the common fish species e.g.: bream, bullhead species, gibel carp, perch, roach, white bream, and sabre carp since 1977. The analysis of the categories due to the diversity and quantity of fish species is not resoluble. The total yearly catches of two fish categories of the fisheries company showed comparable tendency (Fig. 19.) (Weiperth et al., 2008, 2009).

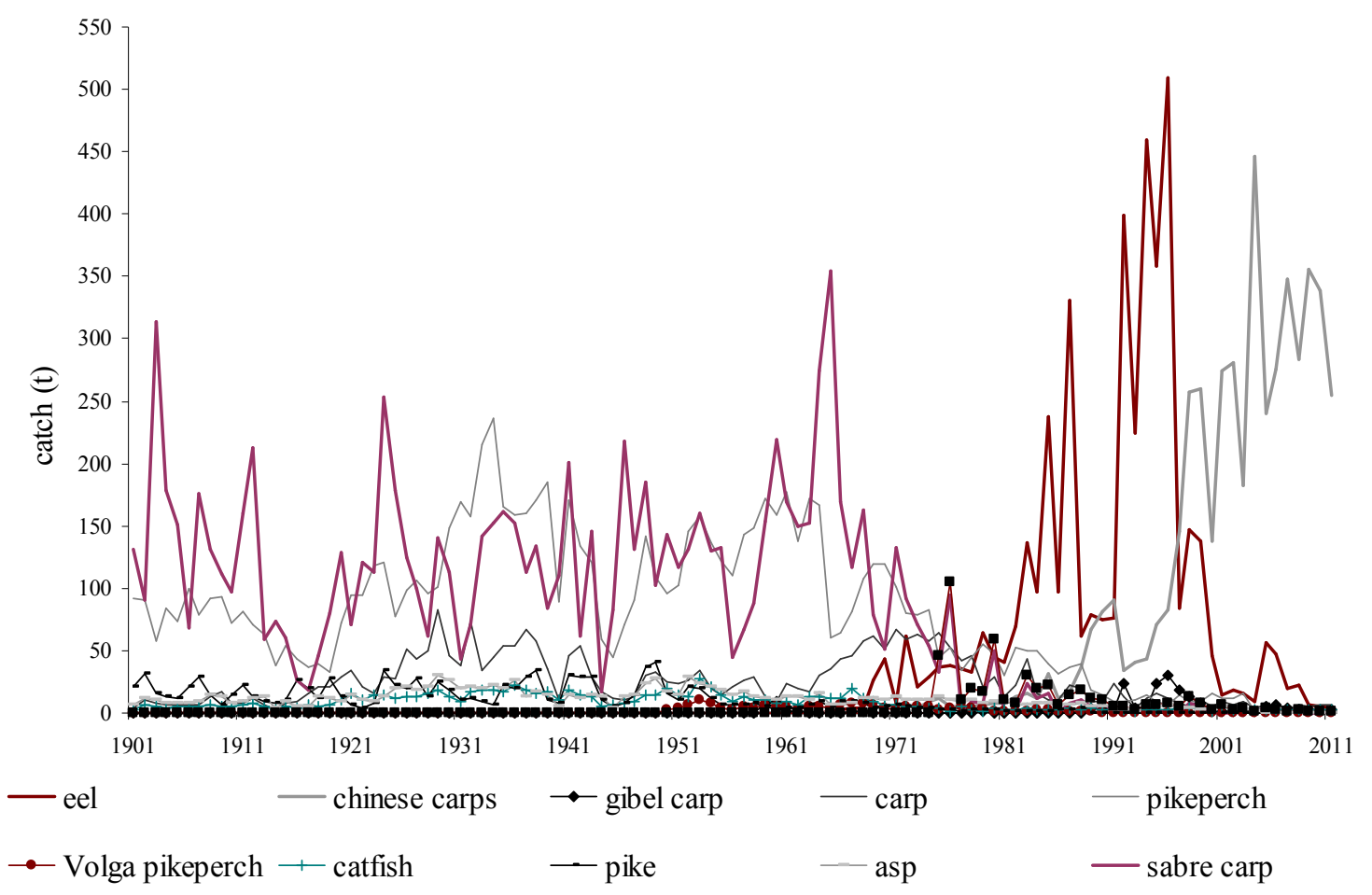

Figure 18. The economical important fish catches in Lake Balaton between 1901-2011 


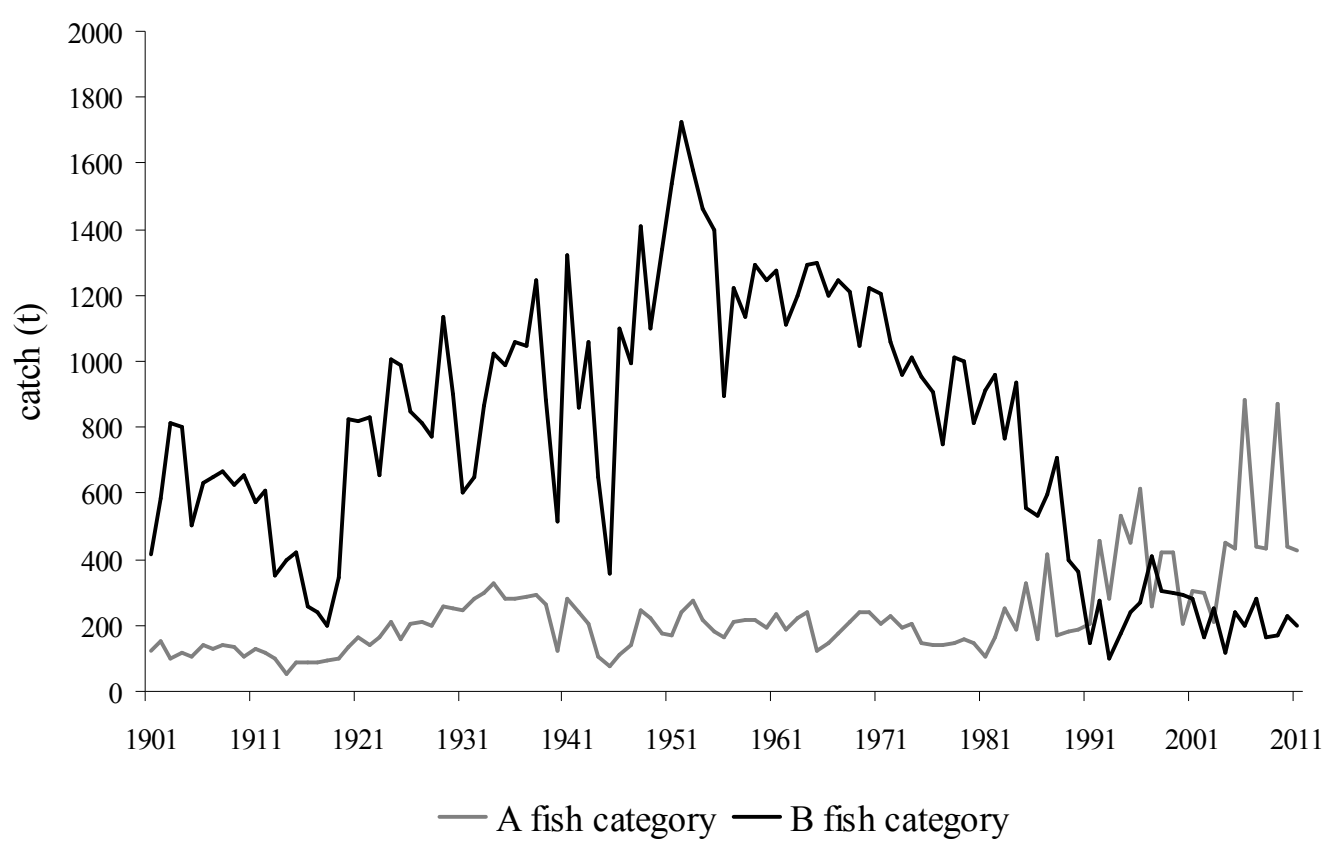

Figure 19. The catches of the two categories of fisheries in Lake Balaton between 1901-2011

The decreasing tendencies of both categories were observed since the middle of the 1980s', when the intensive selective fishing of eel and the other non-native fish species began. The catch of all native fish species have gradually reduced since 1977 (Weiperth et al., 2008, 2009, Specziár, 2010).

\section{Native fish species}

According to the special literature stock size changes of certain species correlates with water level fluctuations, while the catch of others does not. Changes in correlation coefficients show a specific dynamics for most species in Lake Balaton. Based on fisheries and anglers' catch data, the rise in eel catches till the fish kill in 1991 resulted from intensification of fishery. The enhanced selective eel fishing was followed by a second fish kill, eel catch reached its maximum in $1996(509 \mathrm{t})$, than a continuous decrease was experienced, due natural mortality and selective fishing (Fig. 3., Fig. 18.). After electric fishing was stopped, the eel traps near the Sió sluice have been the most important catch methods in Lake Balaton. These fixed traps utilise the catadromous nature of the adult eel, when the water-tapping is moving. Efficiency of catch of the traps significantly depends on the quantity of water-tapping. Analyses have revealed that in case of positive water balance, eel catch of traps increase in parallel with the quantity of regulated outflow. Efficiency of traps is significantly affected by the fact that in case of negative water balance, sluices are kept closed even for years. When analysing anglers' catch, water level changes should also be taken into consideration, as eel has the highest abundance in the littoral, finding appropriate food and shelter in the reed and along the rip-raps (Gönczy and Tölg, 1997). The decrease of anglers' catch data were observed in many years, when the water level was drawn back from the littoral zone. It is very difficult to give a quantitative estimate on the actual stock size of 
eel in the lake. Since stocking was stopped, the stock has been continuously decreasing and ageing. Actually, there have been no studies initiated to follow these changes.

It should be noted, that other background variables (e.g.: number of active fisheries days pro year, number of anglers pro year, long-term data sets of environmental variables) might play also important role in the system and affected the result of cross correlations. These datasets were omitted from our study, due their unreliability. As a result only the first year period can properly be discussed in the view of crosscorrelation analysis of each fish species. Exact assessment of our results, detected several decades later, needs much more reliable data not only about stocks of fish species, but also other background variables.

Lower water level had a positive influence on the share of predator species reproducing in lake. Asp and pikeperch quantity indicated that hard bottom plays a key factor in the reproduction strategy of both species (Balon, 1975, 1990, Bíró, 1985, Weiperth et al., 2008, 2009). Here, when the water level is low, the water body warms up sooner, hatching time gets shorter and - supposing that other environmental parameters are also favourable - most possibly survival rate of the eggs is higher. The reproduction and feeding of catfish are greatly connected to the littoral, therefore its catch data significantly correlated with higher water levels. Negative correlation given for pike might be explained by the fact that it requires shallow areas for spawning, which warm up faster, and the ratio of these habitats is higher when the water level is lower. In anglers' catch, after the 1980s', good year/bad year phenomenon appeared, that is, maximum catch occurs 3-4 years after a successful spawning (1984; 1987-1988). In the 2000s', the catch of pike shows a high fluctuation, however, app. $90 \%$ is provided by anglers. Negative correlation given for pikeperch has already been analysed in detail asp was discussed. It is the temporal pattern of this correlation can be explained by other biotic and abiotic factors, such as stockings or reproduction success of prey fish. However, further studies are needed to clarify the role of these factors. Volga pikeperch showed the highest sensitivity to low water levels, as the maximum catch was given following lowest water levels. This tendency could be experienced till 1987, afterwards a drastic decrease of the catch has started. It raises several questions, as though several studies have been initiated on the biology of this species, the population has been decreasing since 1980 (Fig. 7.) and the stock seems to be unable to grow strong despite low water levels.

When analysing carp catch data, it should be taken into consideration that the recent carp stock can only be maintained by artificial stocking, as the quantity of offspring from natural spawning is negligible (Specziár, 2010). The maintenance of the common carp population depends on the dispersion of the stocks in the water body and its distribution of age-groups. At the evaluation of sabre carp catches the special reproduction strategy of species has to be taken into consideration, and also that the selective fishery of sabre carp was stopped in 1975-76, moreover, in 1982 there was a local sabre carp kill (Staszny and Paulovits, 2007). At present, selective fishery methods are not used to catch sabre carp in Lake Balaton, but every year in some areas it is presented on the fisheries catch (Fig. 10.). The population of the sabre carp in Balaton can be considered stable after the foregoing results of the scientific studies (Staszny and Paulovits, 2007, Specziár, 2010). After the correlation value of sabre carp it could be stated that the spawning of sabre carp in lower water-level is more successful and the maximum of fisheries catch of species can be achieved in three or four years. 


\section{Non-native fish species}

The appearance of grass carp in Lake Balaton, as well as the development of its stock raises numerous questions, as this species has never been legally stocked, moreover, its reproduction has not been proven so far (Pintér, 1980, 1989, 2002; Bíró, 2000 a,b, 2001; Weiperth et al., 2008, 2009; Specziár, 2010, Ferincz et al., 2012, Ferincz, 2013, Kováts et al., 2013). The first specimens were most probably introduced with carp stocks, nowadays this species might reach the lake from fishponds operated on the southern tributaries. Apart from bighead, silver carp and their hybrid species, grass carp is the only species which shows an increasing tendency of the catch (Fig. 15., 16.). Unfortunately, there has been no comprehensive study available on the function of this species in Lake Balaton, nevertheless, there is an increasing need for such a study, because in case the stock size is overgrown the carrying capacity of the lake, it might threaten reeds, which have a constantly worsening condition (Specziár, 2010). In parallel, the terms of fishpond operation in the catchment should be checked and revised, in order to stop recruitment from them.

In the past decades, along with the more and more intensive fishing of bighead and silver carp and their hybrid, catches have shown an increasing trend (Fig. 16.). All these can be the result of new, selective fishing methods (Varga, 2011). In the statistical analyses, however, it might have a masking effect on the possible influence of water level changes. Several studies have been completed addressing the size and structure of the stock as well as the feeding habit of this species (Herodek et al., 1989; Tátrai et al., 2007; Boros et al., 2012), however, data are contradictory. Its reproduction has not been proven, the recruitment of the stock most possibly occurs from the catchment (Tátrai et al., 2009; Boros et al., 2012).

When analysing the fishery data of the gibel carp, it should be taken into consideration that $83 \%$ of the catch is given by the Kis-Balaton Water Protection System (KBWPS), $16 \%$ by the southern fishponds and only $1 \%$ comes from Lake Balaton. The increase of the population started in the 1980s' (Bíró and Paulovits, 1994, Ferincz et al., 2011, 2012). This species hardly appeared in the catch data after it had been introduced to the lake, it reached its maximum catch after the flooding of the first and second stage of the KBWPS. The KBWPS and the density of juvenile coming from the inflows played a main role in the appearance and spread of the gibel carp in Lake Balaton. These factors determined also the population in Balaton until the 2000' years. Since then, the species has been forced back in Lake Balaton. In the fisheries' statistics only the data of fishponds and KBWPS are separately recorded, the catches in Balaton are recorded to the so called $\mathrm{B}$ fish category and also anglers do not have to separate them from the 'other' fish category (Fig. 19.). As a consequence, a detailed evaluation cannot be given about the catches of the species.

Finally, we can conclude that apart from natural factors, utilisation by fishery and anglers might have a significant influence on the size and composition of fish stock in natural waters. There are several papers available discussing this problem (Cane, 1980; Paulovits et al., 1994, 2007; Brämick et al., 2008, Pascual et al., 2007, Humpl et al., 2009; Móreh et al., 2009). When analysing the different fisheries and anglers catches it should not be ignored that the different fisheries-anglers methods applied in Lake Balaton in the different periods have continuously changed (size and time of utilization of the net, time interval of utilisation of knife-net, change of close seasons and size limits), which in some cases decreases the comparability of data. In addition, water level changes affect catches indirectly, influencing applicability of different fishing and 
angling methods via exerting effect on the water depth, quantity and composition of phyto- zooplankton and aquatic macrophytes, macroinvertebrates communities (e.g.: Bíró, 2000a,b, Specziár and Vörös, 2001, Sipkay et al., 2007). It should also be taken into consideration that changes in the size and composition of the fish stock are influenced by both anthropogenic and natural factors. The major shift in the trophic status of the lake which has started in the 1990's (eutrophic/hypertrophic basins have become mesotrophic) initiated such ecological processes which resulted in the drastic reduction of the size of natural fish stock of the lake, as well as lowering of its sustainability.

Acknowledgements. Authors are grateful for two anonymous referees for their valuable comments on the manuscript. The research was supported by the CENTRAL EUROPE Programme (European Lakes Under Environmental Stressors, 2CE243P3). The present article was published in the frame of the project TÁMOP-4.2.2.A-11/1/KONV-2012-0064: „Regional effects of weather extremes resulting from climate change and potential mitigation measures in the coming decades. The project is realized with the support of the European Union, with the co-funding of the European Social Fund. The research of Árpád Ferincz was supported by the European Union and the State of Hungary, co-financed by the European Social Fund in the framework of TÁMOP 4.2.4. A/2-11-1-2012-0001 'National Excellence Program'.

\section{REFERENCES}

[1] Balon, E. K. (1975): Reproductive guilds of fishes: A proposal and definition. - J. Fish Res. Board Can., 32: 821-864.

[2] Balon, E. K. (1990): Epigenesis of an epigeneticist: the development of some alternative concepts on the early ontogeny and evolution of fishes. - Guelph Ichthyology Reviews 1: $1-48$.

[3] Bíró, P. (1978): Exploitation of fishery resources of Lake Balaton. - Verhandlungen der Internationale Vereinigung für Theoretische und Angewandete Limnologie 20(4): 21462149 .

[4] Bíró, P. (1983): On the dynamics of fish populations in Lake Balaton. - Polish Agricultural Annual Series Fisheries 100(3): 55-64.

[5] Bíró, P. (1985): Dynamics of pike-perch, Stizostedion lucioperca (L.) in Lake Balaton. Internationale Revue der gesamten Hydrobiologie 70: 471-490.

[6] Bíró, P. (1997): Temporal variation in Lake Balaton and its fish populations. -Ecology of Freshwater Fish 6(4): 196-216.

[7] Bíró, P, (2000a): Changes in Lake Balaton and its fish populations. In: A. Rossiter H. Kawanabe (EDS.) Biology of Ancient Lakes: Humans Culture and Biodiversity. Advances in Ecological Research 31: 599-611. Academic Press, London

[8] Bíró, P. (2000b): Long-term changes in Lake Balaton and its fish populations. Advances in Ecological Research 31: 599-613.

[9] Bíró, P, (2001): Freshwater Biodiversity: an outlook of objectives, achievements, research fields, and co-operation. - Aquatic Ecosystem Health and Management 4: 251261.

[10] Bíró, P. (2011): Vizsgálati módszerek és értékelő eljárások a halbiológiában [Research methods and evaluating processes in fish biology in Hungarian]. - Debreceni Egyetem Kiadó, Debrecen.

[11] Bíró, P., Specziár, A., Keresztessy. K. (2002): Fish species assemblages in inflowing waters of Lake Balaton. - Verhandlungen der Internationale Vereinigung für Theoretische und Angewandete Limnologie 28(1): 273-278.

[12] Boros, G., Mozsár, A., Petes, K., Mátyás, K., Józsa, V., Tátrai, I. (2012): A busa élőhelye, táplálkozása, növekedése és szaporodása a Balatonban [Habitat, feeding, growth and 
reproduction of introduced Asian carps in Lake Balaton in Hungarian]. - Hidrológiai Közlöny 92(5-6):12-14.

[13] Boros, G., Mozsár, A., Vitál, Z., Nagy, S.A., Specziár, A. (2013): Growth and condition factor of hybrid (Bighead Hypophthalmichthys nobilis Richardson, 1845 x silver carp $H$. molitrix Valenciennes, 1844) Asian carps in the shallow, oligo-mesotrophic Lake Balaton. - Journal of Applied Ichthiology 29: DOI: 10.1111/jai.12325

[14] Brämick, U., Diekman, M., Lemcke, R., Mehner, T. (2008): Assesing shift in fish assembalges of German large lakes by literature data and commercial catch statistics. Archiv für Hydrobiologie 171(2): 87-103.

[15] Cane, A. (1980): The use of anglers' returns in the estimation of fishing sucess. Aquaculture research 11(4): 145-155.

[16] Daskalov, M.G. (2002): Overfishing drives a trophic cascade in the Black Sea. - Marine Ecology Progress Series 225: 53-63.

[17] Dokulil, M.T., Teubner, K., Jagsch, A., Nickus, U., Adrian, R., Straile, D., Jankowski, T., Herzig, A., Padisák J., (2010): The Impact of Climate Change on Lakes in Central Europe. - In: Glen g. (ed.) The impact of climate change in European lakes: 387-409.

[18] Erős, T., Sály, P., Takács, P., Specziár, A., Bíró, P. (2012): Temporal variability in the spatial and environmental determinants of functional metacommunity organization stream fish in a human-modified landscape. - Freshwater Biology 57(9): 1914-1928.

[19] European Union European Regional Development Fund EuLakes Projekt EuLakes Ref. Nr. 2CE243P3 4.3.2. 2ND Report

[20] European Union European Regional Development Fund EuLakes Projekt Ref. Nr. EuLakes Project EuLakes Ref. No. 2CE243P3 4.2., 4.4. Report

[21] Ferincz, Á. (2011): Status of Non-Indigenous Fish Species in the Balaton Catchment. EuLakes Report University of Pannonia, 33 pp.

[22] Ferincz, Á., Staszny, Á., Weiperth, A., Paulovits, G. (2011): Biological invasion of Prussian carp (Carassius gibelio BLOCH): Magnitude and effect on fish fauna of KisBalaton Water Protection System - In: Mócsy et al. VII.. Kárpát-Medencei Környezettudományi Konferencia, I. kötet: 288-292.

[23] Ferincz, Á., Staszny, Á., Ács, A., Weiperth, A., Tátrai, I., Paulovits, G. (2012): Long term development of fish fauna in Lake Fenéki (Kis-Balaton Water Protection System, Hungary): succession, invasion and stabilization. - Acta Zoologica Academiae Scientiarum Hungaricae 58(Suppl.): 3-18.

[24] Gönczy, J., Tölg, I. (1997): Az angolna Magyarországon (múlt, jelen és javaslat a jövőre) [The story of eel in Hungary in Hungarian]. - Halászatfejlesztés 20: 83-89.

[25] Hammer, R., Harper, D. A. T., Ryan, P. D. (2001): PAST: Paleontological Statistics software package for education and data analysis. - Paleontological Electronica 4 (1): 19.

[26] Harka, Á., Sallai, Z. (2004): Magyarország halfaunája [Fishfauna of Hungary in Hungarian]. - Nimfea Természetvédelmi Egyesület, Szarvas

[27] Herman O. (1887): A magyar halászat könyve [Book of the Hungarian Fishery in Hungarian]. I-II. - K. M. Természettudományi Társulat, Budapest

[28] Hobbs, J.R., Norton D.A. (1996): Towards a Conceptual Framework for Restoration Ecology. Restoration Ecology 4(2): 93-110.

[29] Humpl, M., Pivnička, K., Jankovský, M. (2009): Sport fishery statistics, water quality and fish assemblges in the Beronka River in 1975-2005. - Folia Zoologica 58(4):457-465.

[30] Istvánovics, V., Clement, A., Somlyódy, L., Specziár, A., G-Tóth, L., Padisák, J. (2007): Updating water quality targets for shallow Lake Balaton (Hungary), recovering from eutrophication. - Hydobiologia 581: 305-318.

[31] Jeppesen, E., Søndergaard, M., Peder, J. J., Havens E. K., Anneville, O., Carvalho, L., Coveney, F. M., Deneke. R., Dokulil, T. M., Foy B., Gerdeaux, D., Hampton, E. S., Hilt, S., Kangur, K., Köhler, J., Lammens H. H. R. E., Lauridsen L. T., Manca, M., Miracle, R. 
M., Moss, B., Nöges, P., Persson, G., Phillips, G., Portielje, R., Romo, S., Schelske, L. C., Straile D., Tatrai, I., Willen, E., Winder, M. (2005): Lake responses to reduced nutrient loading - an analysis of contemporary long-term data from 35 case studies. Freshwater Biology 50(10): 1747-1771.

[32] Korponai, J., Braun, M., Buczkó, K., Gyulai, I., Forró, L., Nédli, J., Papp, I. (2009): Transition from shallow lake to a wetland: a multi-proxy case study in Zalavári Pond, Lake Balaton, Hungary. - Hydrobiologia 641: 225-244.

[33] Korponai, J., Varga, A.K., Lengré, T., Papp, I., Tóth, A., Braun, M. (2011): Paleolimnological reconstruction of the trophic state in Lake Balaton (Hungary) using Cladocera remains. - Hydrobiologia 676: 237-248.

[34] Kováts, N., Horváth, E., Ferincz, Á., Benkő-Kiss, Á., Paulovits, G. (2013): New and Invasive Species: Lake Balaton, EuLakes Report 4.2.2, University of Pannonia, 33 pp.

[35] Lake, P. S., Palmer, M. A., Bíró, P., Cole, J., Covich, A. P., Dahm, C., Gibert, J., Goedkoop, W., Martensk, K., Verhoeven, J., (2001): Global change and the Biodiversity of Freshwater Ecosystem: Impacts on Linkage between Above-Sendiment and Sendiment Biota. - BioSience 50(12): 1099-1104.

[36] Lukács, K. (1932): A Balaton halai gyakoriságáról [The frequency of fishes of the Lake Balaton in Hungarian]. - Magyar Biol. Kut. Munk. 5: 17-27.

[37] Lyche-Solheim, A., Feld, K. C., Birk, S., Phillips, G., Carvalho, L., Morabito, G., Mischke, U., Willby, N., Søndergaard, M., Hellsten, S., Kolada, A., Mjelde, M., Böhmer, J., Miler, O., T. Pusch, T. M., Argillier, C. (2013): Ecological status assessment of European lakes: a comparison of metrics for phytoplankton, macrophytes, benthic invertebrates and fish. - Hydrobiologia 704: 57-74.

[38] Mátyás, K., Korponai, J., Tátrai, I., Paulovits, G. (2004): Long term effect of cyprinid fishes on phytoplankton and zooplankton communities in a shallow water protection reservoir. - International Review of Hydrobiology 89(1): 68-78.

[39] Móreh, Á., Jordán, F., Szilágyi, A., Scheuring, I. (2009): Overfishing and regime shift sin minimal food web models. - Community Ecology 10(2): 236-243.

[40] Olden, J., D., Neff, B., D. (2001): Cross-correlation bias in lag analysis of aquatic time series. - Marine Biology 138: 1063-1070.

[41] Padisák, J. (1998): Sudden and gradual responses of phytoplankton to global climatic change: case studies from two large, shallow lakes (Balaton, Hungary; Neusiedlersee, Austria/Hungary), - In: D.G. George, J.G. Jones, P. Puncochar, C.S. Reynolds and D.W. Sutcliffe (eds.), Management of lakes and reservoirs during global change: 111-125.

[42] Padisák, J., Molnár, G., Soróczki-Pintér, É., Hajnal, É., George, D.G. (2006): Four consecutive dry years in Lake Balaton (Hungary): consequences for phytoplankton biomass and composition, - Verhandlungen der internationalen Vereinigung für theorethische und angewandte Limnologie 29: 1153-1159.

[43] Pascual, M. A., Cussac, V., Dyer, B., Soto, D., Vigliano, P., Ortubay, S., Macchi, P. (2007): Freshwater fishes of Patagonia in the 21st Century after a hundred years of human settlement, species introductions, and environmental change, - Aquatic Ecosystem Health and Management 10(2): 212-227.

[44] Paulovits, G., Bíró, P. (1991): Hydroacoustic studies on fish stock distribution in Lake Balaton. - Verhandlungen der Internationale Vereinigung für Theoretische und Angewandete Limnologie 24: 2517-2518.

[45] Paulovits, G., Tátrai, I., Bíró, P., Perényi, M., Lakatos, Gy. (1994): Fish stock structure in the littoral zone of Lake Balaton. - Verhandlungen Der Internationale Vereinigung Für Theoretische Und Angewandete Limnologie 25(4): 2162-2163.

[46] Paulovits, G., Borbély, G., Tóth, L. G., Kováts, N. (2007): Effects of water level fluctuation on reproduction and spawning habits of fish species in Lake Balaton. Environmental Engineering and Management 6(5): 467-471. 
[47] Pintér, K. (1980): Exotic fishes in Hungarian waters: their importance in fishery utilization of natural water bodies and fish farming. - Aquaculture research 11(4): 163167.

[48] Pintér, K. (1989, 2002): Magyarország halai [Fishes of Hungary in Hungarian]. Akadémiai Kiadó, Budapest

[49] Pomogyi, P. (1993): Nutrient retention by the Kis-Balaton Water Protection System. Hydrobiologia 251: 309-320.

[50] Ponyi, J. (2001): Áttekintés a Balaton faunisztikai kutatásáról és faunájának összetételéről [An outline of the faunal research of Lake Balaton and the composition of its fauna in Hungarian]. - Állatani Közlemények 86: 3-13.

[51] Probst, W., N., Stelzenmüller, W., Fock, H., O. (2011): Using cross-correlations to assess the relationship between time-lagged pressure and state indicators: an exemplary analysis of North Sea fish population indicators. - ICES Journal of Marine Science 69(4): 670681.

[52] Sály, P., Takács, P., Kiss, I., Bíró, P., Erős, T. (2011): The relative influence of spatial context and catchment- and site-scale environmental factors on stream fish assemblages in a human-modified landscape. - Ecology of Freshwater Fish 20(2): 251-262.

[53] Scheffer, M., Van Geest, G. J., Zimmer, K., Jeppesen, E., Søndergaard, M., Butler, M.g., Hanson, M.A., Declerck, S., De Meester, L. (2006): Small habitat size and isolation can promote species richness: second-order effects on biodiversity in shallow lakes and ponds. - Oikos 112(1): 227-231.

[54] Smith, V.H. (2003) Eutrophication of freshwater and coastal marine ecosystems: a global problem. - Environmental Science and Pollution Research, 10: 126-139.

[55] Sipkay, Cs., Hufnagel, L., Révész, A., Petrányi, G. (2007): Seasonal dynamics of an aquatic macroinvertebrate assembly (Hydrobiological case study of Lake Balaton, No. 2) - Applied Ecology and Environmental Research 5(2): 63-78.

[56] Sipkay, Cs., Kiss, K.T., Vadadi-Fülöp, Cs., Hufnagel, L. (2009): Trends in research on the possible effects of climate change concerning aquatic ecosystems with special emphasis on the modelling approach. - Applied Ecology and Environmental Research 7(2): 171-198.

[57] Somlyódy, L., Honti, M. (2005): The case of Lake Balaton: How can we exercise precaution? - Water Science and Technology 52(6): 195-203.

[58] Søndergaard, M., Liboriussen, L., Pedersen, R.A., Jeppesen, E. (2008): Lake Restoration by Fish Removal: Short- and Long-Term Effects in 36 Danish Lakes. - Ecosystems 11: $1291-1305$.

[59] Specziár, A., Bíró, P. (1998): Spatial distribution and short-term changes of benthic macrofauna in Lake Balaton (Hungary). - Hydrobiologia 389: 203-216.

[60] Specziár, A., Bíró, P., Tölg, L. (1998): Feeding and competition of five cyprinid fishes in different habitats of the Lake Balaton littoral zone, Hungary. - Italian Journal of Zoology 65(Suppl.): 331-336.

[61] Specziár, A., György-Ágnes, I., Erős, T. (2013): Within-lake distribution patterns of fish assemblages: the relative roles of spatial, temporal and random environmental factors in assessing fish assemblages using gillnets in a large and shallow temperate lake. - Journal of Fish Biology 82(3): 840-855.

[62] Specziár, A., Vörös, L. (2001): Long term dynamics of Lake Balaton's chironomid fauna and its dependence on the phytoplankton production. - Archiv für Hydrobiologie 52(1): 119-142.

[63] Specziár, A. (2010): A Balaton hafaunája: A halállományok összetétele, az egyes halfajok életkörülményei és a halállományok korszerü hasznosításának feltételrendszere [Fish fauna of Lake Balaton: stock composition, living conditions of fish and directivies of the modern utilization of fish stock in Hungarian]. - Acta Biologica Debrecina Supplementum 23. 
[64] Szabó, I., Héri, J. (1998): A balatoni Halászati Részvénytársaság halgazdálkodása a KisBalatonon a természetvédelem tükrében [Fish breeding of the fishing of Lake Balaton corporation in view of nature preservation in Hungarian]. - Halászatfejlesztés 21: 21-31.

[65] Staszny, Á., Paulovits, G. (2007): A garda (Pelecus cultratus L.) növekedésének vizsgálata a Balatonban [Growth analysis of razor fish (Pelecus cultratus L.) in Lake Balaton in Hungarian]. - Hidrológiai közlöny 87(6): 122-123.

[66] Takács, P., Specziár, A., Erős, T., Sály, P., Bíró, P. (2011): A balatoni vízgyüjtő halállományainak összetétele [Checklist of fish species inhabiting the drainage system of Lake Balaton in Hungarian]. - Ecology of Lake Balaton/A Balaton ökológiája, 2011, Vol. $1(1): 1-21$.

[67] Tátrai, I., Istvánovics, V. (1986): The role of fish in the regulation of nutrient cycling in Lake Balaton. Freshwater Biology 16(3): 417-424.

[68] Tölg, L., Specziár, A., Bíró, P. (1998): A halállomány faj szerinti összetételének vizsgálata paneles kopoltyúhálóval a Balaton parti sávjában [Study of fish stock using multi-mesh gillnet in Lake Balaton in Hungarian]. - Halászatfejlesztés 21: 136-145.

[69] Van De Bund, W.J., Van Donk, E. (2002): Short-term and long-term effects of zooplanktivorous fish removal in a shallow lake: a synthesis of 15 years of data from Lake Zwemlust. - Freshwater Biology 47(12): 2380-2387.

[70] Vadadi-Fülöp, Cs., Sipkay, Cs., Mészáros, G., Hufnágel, L. (2012):_Climate change and freshwater zooplankton: what does it boil down to? - Aquatic Ecology 46(4): 501-519.

[71] Varga, L. (2011): Régi új írányelvek a Balaton halgazdálkodásában [Old-new guidelines for fisheries management of Lake Balaton in Hungarian]. - Pisces Hungarici 5: 129-133.

[72] Várkuti, A., Kovács, K., Stenger-Kovács, C., Padisák, J. (2008):_Environmental awareness of the permanent inhabitants of towns and villages on the shores of Lake Balaton with special reference to issues related to global climate change. Hydrobiologia 599: 249-257.

[73] Verasztó, Cs., Kiss-Keve, T., Sipkay, Cs., Gimesi, L., Vadadi-Fülöp, Cs., Türei, D., Hufnagel, L. (2010): Long-term dynamic patterns and diversity of phytoplankton communities in large eutrophic river (the case of River Danube, Hungary. - Applied ecology and enviromental research 8(4): 329-349.

[74] Vutskits, Gy. (1897): A Balaton halai és gyakoriságuk [The fish species of the Lake Balaton and there frequency in Hungarian]. - Természettudományi Közlemények 29: 593-595.

[75] Weiperth, A., Paulovits, G., Staszny, Á. (2008): A vízszintingadozás hatása a halállomány szaporodására [The effect of water level fluctuation on the reproduction of fish stock in Lake Balaton in Hungarian]. - Hidrológiai Közlöny 88(6): 234-236.

[76] Weiperth, A., Szivák, I., Ferincz, Á., Staszny, Á., Keresztessy, K., Paulovits G. (2009): A vizszintingadozás hatása a balatoni halász-horgász fogások alakulására [Effects of water level fluctuation on fish catch in Lake Balaton in Hungarian]. - Állattani Közlemények, 94(2): 199-213.

[77] Zákonyi B. (2004): Balaton és vidéke [Balaton and region in Hungarian]. Horgász. Kul.Túra. Útikönyv. - Tudex Kiadó Kft. Budapest 


$$
-244 \text { - }
$$

\section{Appendices}

Appendix 1. The fisheries catches of 9 economical important fish species and the cumulate data of silver carp, bighead carp and their hybrids in Lake Balaton between 1901-2011

\begin{tabular}{|c|c|c|c|c|c|}
\hline \multirow[b]{2}{*}{ Year } & \multicolumn{5}{|c|}{ Fish species / catch in tons } \\
\hline & $\begin{array}{l}\text { asp (Aspius } \\
\quad \text { aspius) }\end{array}$ & $\begin{array}{l}\text { carp (Cyprinus } \\
\text { carpio })\end{array}$ & $\begin{array}{l}\text { catfish (Silurus } \\
\text { glanis) }\end{array}$ & $\begin{array}{l}\text { bighead carp, silver carp and their hybrid } \\
\text { (Hypopthalmichthys molitrix, H. nobilis) }\end{array}$ & $\begin{array}{c}\text { eel (Anguila } \\
\text { anguila) }\end{array}$ \\
\hline 1901 & 5.92 & 4.5 & 2.34 & - & - \\
\hline 1902 & 11.33 & 10.0 & 6.30 & - & - \\
\hline 1903 & 11.06 & 8.5 & 4.93 & - & - \\
\hline 1904 & 7.53 & 7.2 & 4.15 & - & - \\
\hline 1905 & 7.96 & 7.0 & 4.73 & - & - \\
\hline 1906 & 7.76 & 6.7 & 5.08 & - & - \\
\hline 1907 & 9.26 & 6.9 & 5.31 & - & - \\
\hline 1908 & 15.00 & 13.6 & 6.12 & - & - \\
\hline 1909 & 13.38 & 17.5 & 5.45 & - & - \\
\hline 1910 & 7.73 & 8.0 & 4.72 & - & - \\
\hline 1911 & 9.36 & 8.5 & 6.17 & - & - \\
\hline 1912 & 11.39 & 11.4 & 7.46 & - & - \\
\hline 1913 & 12.73 & 6.6 & 5.68 & - & - \\
\hline 1914 & 3.35 & 3.0 & 2.12 & - & - \\
\hline 1915 & 8.67 & 8.2 & 5.64 & - & - \\
\hline 1916 & 4.87 & 9.5 & 3.44 & - & - \\
\hline 1917 & 5.53 & 15.6 & 6.42 & - & - \\
\hline 1918 & 13.24 & 21.2 & 4.81 & - & - \\
\hline 1919 & 11.24 & 20.4 & 6.72 & - & - \\
\hline 1920 & 9.22 & 29.3 & 10.21 & - & - \\
\hline 1921 & 13.78 & 33.9 & 15.43 & - & - \\
\hline 1922 & 10.76 & 20.7 & 11.14 & - & - \\
\hline 1923 & 9.31 & 15.9 & 15.04 & - & - \\
\hline 1924 & 13.51 & 28.8 & 14.98 & - & - \\
\hline 1925 & 19.58 & 28.0 & 11.84 & - & - \\
\hline 1926 & 20.64 & 51.3 & 13.37 & - & - \\
\hline 1927 & 19.00 & 43.1 & 13.30 & - & - \\
\hline 1928 & 21.10 & 50.0 & 15.20 & - & - \\
\hline 1929 & 29.92 & 82.4 & 17.87 & - & - \\
\hline 1930 & 25.89 & 45.4 & 13.20 & - & - \\
\hline 1931 & 19.24 & 37.8 & 9.52 & - & - \\
\hline 1932 & 21.65 & 73.4 & 16.84 & - & - \\
\hline 1933 & 19.07 & 34.6 & 18.66 & - & - \\
\hline 1934 & 22.02 & 44.7 & 18.48 & - & - \\
\hline 1935 & 19.87 & 53.7 & 17.49 & - & - \\
\hline 1936 & 25.99 & 53.4 & 22.25 & - & - \\
\hline 1937 & 12.73 & 66.7 & 18.81 & - & - \\
\hline 1938 & 16.41 & 58.3 & 15.50 & - & - \\
\hline 1939 & 13.92 & 36.0 & 16.88 & - & - \\
\hline 1940 & 5.60 & 10.7 & 9.95 & - & - \\
\hline 1941 & 14.52 & 45.7 & 18.34 & - & - \\
\hline 1942 & 11.59 & 53.2 & 14.71 & - & - \\
\hline 1943 & 14.48 & 29.0 & 13.56 & - & - \\
\hline 1944 & 13.39 & 16.5 & 5.80 & - & - \\
\hline 1945 & 4.11 & 12.4 & 6.54 & - & - \\
\hline 1946 & 13.68 & 11.1 & 8.12 & - & - \\
\hline 1947 & 14.91 & 13.2 & 9.68 & - & - \\
\hline 1948 & 23.56 & 29.7 & 14.42 & - & - \\
\hline 1949 & 27.35 & 33.3 & 14.39 & - & - \\
\hline 1950 & 16.62 & 25.1 & 20.30 & - & - \\
\hline
\end{tabular}


Weiperth et al.: Effect of water level fluctuations on fishery and anglers' catch data of economically utilised fish species of Lake Balaton between 1901 and 2011 -245 -

\begin{tabular}{|c|c|c|c|c|c|}
\hline \multirow[b]{2}{*}{ Year } & \multicolumn{5}{|c|}{ Fish species / catch in tons } \\
\hline & $\begin{array}{l}\text { asp (Aspius } \\
\text { aspius) }\end{array}$ & $\begin{array}{l}\text { carp (Cyprinus } \\
\text { carpio })\end{array}$ & $\begin{array}{l}\text { catfish (Silurus } \\
\text { glanis) }\end{array}$ & $\begin{array}{l}\text { bighead carp, silver carp and their hybrid } \\
\text { (Hypopthalmichthys molitrix, H. nobilis) }\end{array}$ & $\begin{array}{l}\text { eel (Anguila } \\
\text { anguila) }\end{array}$ \\
\hline 1951 & 14.73 & 23.6 & 14.87 & - & - \\
\hline 1952 & 28.48 & 25.7 & 13.38 & - & - \\
\hline 1953 & 23.58 & 34.1 & 27.90 & - & - \\
\hline 1954 & 21.39 & 19.2 & 21.60 & - & - \\
\hline 1955 & 18.92 & 14.2 & 13.88 & - & - \\
\hline 1956 & 14.77 & 21.3 & 8.59 & - & - \\
\hline 1957 & 17.00 & 25.6 & 12.84 & - & - \\
\hline 1958 & 13.74 & 28.9 & 10.47 & - & - \\
\hline 1959 & 11.43 & 12.8 & 10.82 & - & - \\
\hline 1960 & 10.11 & 9.7 & 7.86 & - & - \\
\hline 1961 & 13.31 & 23.6 & 9.09 & - & - \\
\hline 1962 & 13.50 & 19.6 & 7.02 & - & - \\
\hline 1963 & 10.19 & 17.0 & 12.92 & - & - \\
\hline 1964 & 15.73 & 29.9 & 12.91 & - & 0.2 \\
\hline 1965 & 6.20 & 34.9 & 11.75 & - & 1.1 \\
\hline 1966 & 6.68 & 42.8 & 12.08 & - & 2.3 \\
\hline 1967 & 8.29 & 46.0 & 19.91 & - & 3.5 \\
\hline 1968 & 12.32 & 58.0 & 12.38 & - & 4.4 \\
\hline 1969 & 12.23 & 61.2 & 9.06 & - & 25.6 \\
\hline 1970 & 10.99 & 51.5 & 6.89 & - & 42.8 \\
\hline 1971 & 13.34 & 66.6 & 7.01 & - & 8.1 \\
\hline 1972 & 10.56 & 59.3 & 5.88 & 0.1 & 61.4 \\
\hline 1973 & 10.39 & 63.0 & 5.36 & 3.7 & 21.0 \\
\hline 1974 & 10.30 & 58.2 & 4.11 & 9.0 & 29.4 \\
\hline 1975 & 12.53 & 63.7 & 3.70 & 11.6 & 36.6 \\
\hline 1976 & 10.97 & 52.6 & 1.91 & 5.2 & 38.1 \\
\hline 1977 & 9.69 & 42.1 & 5.20 & 5.1 & 35.8 \\
\hline 1978 & 10.05 & 46.0 & 2.03 & 5.8 & 32.2 \\
\hline 1979 & 8.06 & 20.7 & 1.89 & 6.0 & 64.4 \\
\hline 1980 & 8.57 & 29.0 & 4.15 & 8.1 & 44.3 \\
\hline 1981 & 9.53 & 13.3 & 2.57 & 8.0 & 40.5 \\
\hline 1982 & 6.53 & 21.7 & 2.31 & 13.5 & 70.0 \\
\hline 1983 & 6.16 & 43.2 & 3.81 & 16.0 & 135.9 \\
\hline 1984 & 8.15 & 15.4 & 2.61 & 11.9 & 97.4 \\
\hline 1985 & 7.51 & 11.0 & 2.27 & 31.9 & 238.1 \\
\hline 1986 & 6.96 & 10.1 & 2.30 & 11.2 & 97.7 \\
\hline 1987 & 7.11 & 21.7 & 4.19 & 16.4 & 331.3 \\
\hline 1988 & 7.68 & 19.5 & 3.06 & 36.6 & 61.1 \\
\hline 1989 & 5.74 & 8.8 & 3.75 & 67.2 & 78.4 \\
\hline 1990 & 5.25 & 8.8 & 2.18 & 82.0 & 74.3 \\
\hline 1991 & 2.43 & 23.1 & 4.43 & 91.0 & 76.8 \\
\hline 1992 & 2.91 & 13.0 & 2.01 & 33.5 & 399.2 \\
\hline 1993 & 1.12 & 4.0 & 1.44 & 40.3 & 225.1 \\
\hline 1994 & 5.31 & 11.5 & 2.55 & 43.8 & 459.9 \\
\hline 1995 & 4.65 & 15.8 & 3.25 & 70.4 & 357.9 \\
\hline 1996 & 6.70 & 11.4 & 2.17 & 83.1 & 509.4 \\
\hline 1997 & 4.33 & 8.3 & 4.42 & 146.0 & 84.6 \\
\hline 1998 & 4.34 & 5.2 & 3.53 & 257.7 & 147.0 \\
\hline 1999 & 3.24 & 11.0 & 4.18 & 259.3 & 138.4 \\
\hline
\end{tabular}


Weiperth et al.: Effect of water level fluctuations on fishery and anglers' catch data of economically utilised fish species of Lake Balaton between 1901 and 2011

$$
-246-
$$

\begin{tabular}{c|ccccc}
\hline \multirow{2}{*}{ Year } & \multicolumn{5}{|c}{ Fish species / catch in tons } \\
\cline { 2 - 6 } & $\begin{array}{c}\text { asp (Aspius } \\
\text { aspius) }\end{array}$ & $\begin{array}{c}\text { carp (Cyprinus } \\
\text { carpio })\end{array}$ & $\begin{array}{c}\text { catfish (Silurus } \\
\text { glanis) }\end{array}$ & $\begin{array}{c}\text { bighead carp, silver carp and their hybrid } \\
\text { (Hypopthalmichthys molitrix, H. nobilis) }\end{array}$ & $\begin{array}{c}\text { eel (Anguila } \\
\text { anguila) }\end{array}$ \\
\hline 2000 & 3.13 & 5.7 & 1.28 & 137.9 & 45.8 \\
2001 & 5.74 & 8.9 & 5.73 & 274.7 & 14.0 \\
2002 & 2.75 & 6.5 & 2.96 & 281.1 & 19.0 \\
2003 & 2.45 & 9.4 & 4.39 & 182.6 & 16.0 \\
2004 & 0.84 & 4.6 & 2.31 & 446.9 & 8.6 \\
2005 & 0.41 & 7.0 & 2.86 & 240.5 & 56.7 \\
2006 & 0.37 & 4.2 & 3.01 & 275.0 & 47.6 \\
2007 & 0.31 & 3.0 & 2.56 & 347.8 & 19.7 \\
2008 & 0.33 & 6.1 & 2.64 & 284.0 & 22.7 \\
2009 & 0.30 & 5.2 & 2.65 & 356.0 & 6.6 \\
2010 & 0.31 & 6.4 & 3.09 & 338.1 & 5.6 \\
2011 & 0.30 & 7.1 & 2.73 & 254.4 & 4.4
\end{tabular}




$$
-247 \text { - }
$$

\begin{tabular}{|c|c|c|c|c|c|c|}
\hline \multirow[b]{2}{*}{ Year } & \multirow[b]{2}{*}{$\begin{array}{l}\text { gibel carp } \\
\text { (Carassius } \\
\text { gibelio ) }\end{array}$} & \multicolumn{5}{|c|}{ Fish species / catch in tons } \\
\hline & & $\begin{array}{l}\text { pike (Esox } \\
\text { lucius) }\end{array}$ & $\begin{array}{l}\text { pikeperch } \\
\text { (Sander } \\
\text { lucioperca) } \\
\end{array}$ & $\begin{array}{l}\text { sabre carp } \\
\text { (Pelecus } \\
\text { cultratus }) \\
\end{array}$ & $\begin{array}{l}\text { Volga pikeperch } \\
\text { (Sander volgensis) }\end{array}$ & $\begin{array}{c}\text { grass carp } \\
(\text { Ctenopharyngodon } \\
\text { idella })\end{array}$ \\
\hline 1901 & - & 20.51 & 92.30 & 130.951 & - & - \\
\hline 1902 & - & 31.24 & 90.56 & 90.225 & - & - \\
\hline 1903 & - & 16.20 & 58.19 & 313.657 & - & - \\
\hline 1904 & - & 13.71 & 84.23 & 178.309 & - & - \\
\hline 1905 & - & 11.93 & 74.02 & 150.85 & - & - \\
\hline 1906 & - & 21.31 & 100.18 & 68.051 & - & - \\
\hline 1907 & - & 28.81 & 78.24 & 176.001 & - & - \\
\hline 1908 & - & 14.93 & 91.74 & 130.837 & - & - \\
\hline 1909 & - & 6.82 & 93.40 & 112.003 & - & - \\
\hline 1910 & - & 13.88 & 72.24 & 97.01 & - & - \\
\hline 1911 & - & 22.52 & 81.78 & 159.524 & - & - \\
\hline 1912 & - & 12.91 & 71.23 & 212.035 & - & - \\
\hline 1913 & - & 9.20 & 62.89 & 59.101 & - & - \\
\hline 1914 & - & 8.38 & 38.20 & 73.405 & - & - \\
\hline 1915 & - & 10.26 & 53.71 & 60.849 & - & - \\
\hline 1916 & - & 26.18 & 43.52 & 26.348 & - & - \\
\hline 1917 & - & 20.11 & 37.37 & 18.187 & - & - \\
\hline 1918 & - & 11.71 & 39.97 & 45.379 & - & - \\
\hline 1919 & - & 27.81 & 32.32 & 80.102 & - & - \\
\hline 1920 & - & 12.91 & 71.54 & 129.215 & - & - \\
\hline 1921 & - & 6.29 & 94.35 & 70.313 & - & - \\
\hline 1922 & - & 3.95 & 94.62 & 120.419 & - & - \\
\hline 1923 & - & 8.04 & 117.53 & 112.792 & - & - \\
\hline 1924 & - & 34.21 & 120.86 & 253.798 & - & - \\
\hline 1925 & - & 22.08 & 77.21 & 178.338 & - & - \\
\hline 1926 & - & 20.06 & 98.58 & 124.282 & - & - \\
\hline 1927 & - & 27.60 & 106.40 & 99.5 & - & - \\
\hline 1928 & - & 13.60 & 96.20 & 61.2 & - & - \\
\hline 1929 & - & 24.67 & 101.16 & 140.867 & - & - \\
\hline 1930 & - & 18.67 & 148.53 & 112.808 & - & - \\
\hline 1931 & - & 10.00 & 169.01 & 42.998 & - & - \\
\hline 1932 & - & 11.73 & 157.69 & 70.433 & - & - \\
\hline 1933 & - & 9.21 & 214.70 & 141.535 & - & - \\
\hline 1934 & - & 6.54 & 236.77 & 152.034 & - & - \\
\hline 1935 & - & 22.84 & 165.67 & 161.613 & - & - \\
\hline 1936 & - & 19.96 & 159.32 & 152.775 & - & - \\
\hline 1937 & - & 29.33 & 160.65 & 112.816 & - & - \\
\hline 1938 & - & 33.85 & 171.10 & 134.187 & - & - \\
\hline 1939 & - & 10.59 & 185.30 & 83.712 & - & - \\
\hline 1940 & - & 7.93 & 88.73 & 109.734 & - & - \\
\hline 1941 & - & 30.47 & 171.17 & 200.186 & - & - \\
\hline 1942 & - & 28.74 & 134.31 & 62.312 & - & - \\
\hline 1943 & - & 29.02 & 121.11 & 145.075 & - & - \\
\hline 1944 & - & 10.86 & 58.45 & 16.81 & - & - \\
\hline 1945 & - & 5.79 & 45.25 & 83.008 & - & - \\
\hline 1946 & - & 7.28 & 71.12 & 218.399 & - & - \\
\hline 1947 & - & 14.43 & 90.77 & 131.138 & - & - \\
\hline 1948 & - & 37.23 & 141.58 & 185.305 & - & - \\
\hline 1949 & - & 40.89 & 108.61 & 102.727 & - & - \\
\hline 1950 & - & 15.83 & 95.31 & 143.101 & 2.91 & - \\
\hline
\end{tabular}




\begin{tabular}{|c|c|c|c|c|c|c|}
\hline Year & $\begin{array}{c}\text { gibel carp } \\
\text { (Carassius } \\
\text { gibelio ) } \\
\end{array}$ & $\begin{array}{c}\text { pike (Esox } \\
\text { lucius) }\end{array}$ & $\begin{array}{c}\text { pikeperch } \\
\text { (Sander } \\
\text { lucioperca) }\end{array}$ & $\begin{array}{l}\text { Fish species } \\
\text { sabre carp } \\
\text { (Pelecus } \\
\text { cultratus) }\end{array}$ & $\begin{array}{l}\text { catch in tons } \\
\text { Volga pikeperch } \\
\text { (Sander volgensis) }\end{array}$ & $\begin{array}{c}\text { grass carp } \\
\text { (Ctenopharyngodon } \\
\text { idella }) \\
\end{array}$ \\
\hline 1951 & - & 10.48 & 102.60 & 116.563 & 3.62 & - \\
\hline 1952 & - & 20.63 & 145.57 & 131.17 & 6.10 & - \\
\hline 1953 & - & 20.32 & 157.23 & 160.149 & 11.01 & - \\
\hline 1954 & - & 12.16 & 136.73 & 130.064 & 7.73 & - \\
\hline 1955 & - & 6.62 & 121.65 & 132.928 & 4.49 & - \\
\hline 1956 & - & 6.49 & 109.70 & 44.646 & 3.03 & - \\
\hline 1957 & - & 6.50 & 143.08 & 66.922 & 5.00 & - \\
\hline 1958 & - & 8.31 & 148.02 & 87.784 & 4.03 & - \\
\hline 1959 & 7.7 & 5.05 & 172.16 & 153.871 & 6.50 & - \\
\hline 1960 & 9.6 & 2.73 & 158.42 & 219.553 & 5.88 & - \\
\hline 1961 & 1.8 & 3.49 & 176.62 & 169.836 & 5.47 & - \\
\hline 1962 & 1.0 & 4.00 & 138.47 & 149.9 & 2.12 & - \\
\hline 1963 & 0.2 & 6.13 & 171.73 & 151.838 & 4.83 & - \\
\hline 1964 & 0.4 & 8.79 & 166.30 & 274.924 & 5.30 & - \\
\hline 1965 & 0.1 & 5.65 & 60.02 & 354.582 & 3.70 & - \\
\hline 1966 & 0.4 & 9.59 & 64.92 & 169.647 & 6.71 & - \\
\hline 1967 & 0.7 & 9.82 & 81.68 & 117.464 & 7.90 & - \\
\hline 1968 & 0.7 & 7.93 & 107.09 & 162.568 & 7.24 & - \\
\hline 1969 & 0.5 & 3.44 & 119.90 & 78.512 & 6.33 & - \\
\hline 1970 & 0.1 & 4.66 & 119.48 & 50.987 & 3.41 & - \\
\hline 1971 & 0.1 & 6.60 & 101.30 & 132.082 & 3.00 & - \\
\hline 1972 & 0.1 & 5.90 & 80.72 & 91.816 & 4.95 & - \\
\hline 1973 & 0.1 & 3.62 & 79.08 & 71.475 & 5.71 & - \\
\hline 1974 & 0.0 & 4.15 & 82.97 & 53.448 & 4.95 & - \\
\hline 1975 & 0.1 & 2.29 & 44.92 & 33.035 & 3.01 & 36.045 \\
\hline 1976 & 0.3 & 3.10 & 52.50 & 94.274 & 4.18 & 98.449 \\
\hline 1977 & 0.4 & 1.88 & 33.93 & 0.622 & 5.08 & 5.702 \\
\hline 1978 & 0.1 & 2.11 & 45.26 & 9.365 & 4.03 & 13.395 \\
\hline 1979 & 0.7 & 2.19 & 54.53 & 8.467 & 3.43 & 11.9 \\
\hline 1980 & 0.2 & 2.16 & 47.64 & 50.03 & 1.78 & 51.805 \\
\hline 1981 & 0.1 & 1.88 & 30.49 & 1.563 & 1.49 & 3.049 \\
\hline 1982 & 0.1 & 1.61 & 53.05 & 1 & 1.12 & 2.118 \\
\hline 1983 & 0.0 & 1.40 & 49.46 & 23.846 & 1.40 & 25.249 \\
\hline 1984 & 0.0 & 1.36 & 49.47 & 11.333 & 2.15 & 13.478 \\
\hline 1985 & 0.3 & 1.80 & 39.06 & 15.377 & 2.54 & 17.914 \\
\hline 1986 & 0.4 & 2.94 & 31.55 & 0.01 & 1.54 & 1.551 \\
\hline 1987 & 0.7 & 2.25 & 36.85 & 7.57 & 1.60 & 9.167 \\
\hline 1988 & 0.3 & 3.32 & 40.00 & 10.853 & 1.35 & 12.198 \\
\hline 1989 & 3.8 & 0.43 & 18.34 & 5.795 & 0.72 & 6.513 \\
\hline 1990 & 2.2 & 0.57 & 14.39 & 5.517 & 0.60 & 6.12 \\
\hline 1991 & 2.2 & 0.28 & 9.41 & 3.127 & 0.29 & 3.415 \\
\hline 1992 & 23.8 & 0.50 & 8.66 & 2.777 & 0.20 & 2.976 \\
\hline 1993 & 4.4 & 0.35 & 10.23 & 1.629 & 0.28 & 1.906 \\
\hline 1994 & 3.6 & 0.39 & 13.94 & 0.741 & 0.48 & 1.22 \\
\hline 1995 & 23.2 & 0.31 & 9.26 & 1.687 & 0.04 & 1.722 \\
\hline 1996 & 29.9 & 0.32 & 6.05 & 0.698 & 0.03 & 0.725 \\
\hline 1997 & 18.7 & 0.49 & 13.92 & 0.592 & 0.17 & 0.759 \\
\hline 1998 & 12.7 & 0.41 & 9.16 & 8.218 & 0.15 & 8.364 \\
\hline 1999 & 7.5 & 0.47 & 8.60 & 4.987 & 0.06 & 5.051 \\
\hline
\end{tabular}


Weiperth et al.: Effect of water level fluctuations on fishery and anglers' catch data of economically utilised fish species of Lake Balaton between 1901 and 2011

$$
-249 \text { - }
$$

\begin{tabular}{c|cccccc}
\hline Year & $\begin{array}{c}\text { gibel carp } \\
\text { (Carassius } \\
\text { gibelio })\end{array}$ & $\begin{array}{c}\text { pike }(\text { Esox } \\
\text { lucius })\end{array}$ & $\begin{array}{c}\text { pikeperch } \\
\text { (Sander } \\
\text { lucioperca })\end{array}$ & $\begin{array}{c}\text { Fish species / catch in tons } \\
\text { sabre carp } \\
\text { (Pelecus } \\
\text { cultratus })\end{array}$ & $\begin{array}{c}\text { Volga pikeperch } \\
\text { (Sander volgensis })\end{array}$ & $\begin{array}{c}\text { grass carp } \\
\text { (Ctenopharyngodon } \\
\text { idella })\end{array}$ \\
\hline 2000 & 1.3 & 0.84 & 15.88 & 0.032 & 0.04 & 0.074 \\
2001 & 1.0 & 0.42 & 11.79 & 0.26 & 0.01 & 0.269 \\
2002 & 1.2 & 0.19 & 11.82 & 0.268 & 0.02 & 0.29 \\
2003 & 1.7 & 0.32 & 15.33 & 1.495 & 0.00 & 1.499 \\
2004 & 0.7 & 0.06 & 1.62 & 0.934 & 0.01 & 0.939 \\
2005 & 5.1 & 0.08 & 6.50 & 4.001 & 0.01 & 4.007 \\
2006 & 6.0 & 0.05 & 4.12 & 1.788 & 0.04 & 1.828 \\
2007 & 4.4 & 0.04 & 2.67 & 1.134 & 0.02 & 2.139 \\
2008 & 2.1 & 0.04 & 4.60 & 2.109 & 0.03 & 0.395 \\
2009 & 3.0 & 0.05 & 3.33 & 0.385 & 0.01 & 0.399 \\
2010 & 1.9 & 0.04 & 2.11 & 0.379 & 0.02 & 1.019 \\
2011 & 2.3 & 0.04 & 2.89 & 1.009 & 0.01 &
\end{tabular}

